\section{Suomen muinaismuistoyhdistyksen taidehistorialliset tutkimusretket Suomessa 1871-1902}

\author{
Leena Valkeapää
}

Suomen Muinaismuistoyhdistys Finska Fornminnesföreningen perustettiin vuonna 1870. Tavoitteeksi asetettiin aineellisen ja aineettoman kulttuuriperinnön kerääminen, säilyttäminen ja tutkiminen. Yhdistys kokosi piiriinsä monipuolisen joukon Suomen menneisyydestä kiinnostuneita ihmisiä, sillä muinaismuisto-käsitteen alle mahtuivat niin lorut ja leikit, keskiaikaiset kirkot, henkilöhistoriat, retket sukukansojen pariin kuin Suomen historiaan liittyvät tarinatkin. Toiminta kattoi siten arkeologian, taidehistorian, kansatieteen ja kulttuurihistorian, kuten yhdistyksen nykyinen määritelmä asian muotoilee. ${ }^{1}$

Yhdistys järjesti vuosina 1871-1902 kahdeksan kotimaan tutkimusretkeä, jotka loivat perustan Suomen vanhan taiteen historian tutkimukselle. Retkillä etsittiin, dokumentoitiin ja koottiin yhteen tietoa kotimaan taidehistoriallisista kohteista. Ensimmäinen retki työskenteli Suomen taiteen historian kanta-alueeksi käsitetyllä Turun seudulla ja Ahvenanmaalla. Toinen retki jatkoi pohjoiseen päin Ulvilaan asti, seuraavat kolme retkeä tutkivat alueita Länsi-Uudellemaalle ja Hämeeseen päin laajenevina kehinä. Kuudes ja seitsemäs retki suuntasivat Pohjanmaalle, Pohjois-Savoon ja Kainuuseen, kahdeksas uudestaan Lounais-Suomeen. Tutkittu alue sijoittui voimakkaasti läntiseen Suomeen ja länsipainotteisuus olisi jatkunut, sillä vuoden 1903 toteutumattoman retken kohde oli Ahvenanmaa.
Retkikuntien työskentelyn painopiste oli kirkoissa, joiden esineistö, seinämaalaukset ja arkkitehtuuri dokumentoitiin kuvin ja sanoin, mutta ohjelmaan kuului myös kartanoita ja muita profaaneja kohteita. Retket tuottivat valtavan aineiston, yli 2700 piirustusta, akvarellia ja valokuvaa sekä tuhansia sivuja kirjallisia kuvauksia. Perustavalaatuisuudestaan huolimatta retkiä on tutkittu vähän ja aiheen käsittely on ollut suppeuden vuoksi ylimalkaista. $^{2}$

Artikkelini on ensimmäinen koko tutkimusretkisarjan työn, tuloksien ja niiden julkaisun kokonaisvaltainen kuvaus ja alustava anaIyysi. ${ }^{3}$ Selvitän retkikuntien osallistujat, reitit ja kohteet. Tarkastelen retkien loppumisen syytä ja mitä retkillä saatiin aikaan. Lopuksi pohdin myös miksi retkien tulokset ovat jääneet suhteellisen tuntemattomiksi.

\section{Osallistujat}

Tutkimusretkille osallistui yhteensä 28 miestä. Ryhmän kooksi vakiintui toisesta retkestä lähtien neljä henkilöä. ${ }^{4}$ Mukaan tarvittiin ennen kaikkea nopeita ja varmoja piirtäjiä, sillä 


\begin{tabular}{|c|c|c|c|c|}
\hline Vuosi & arkkitehdit & taiteilijat & tutkijat & muut \\
\hline 1871 & Wolmar Westling $(Y)$ & $\begin{array}{l}\text { Albert Edelfelt } \\
\text { Nils Månsson } \\
\text { Mandelgren }\end{array}$ & $\begin{array}{l}\text { Emil Nervander } \\
\text { Eliel Aspelin } \\
\text { (Mandelgren) }\end{array}$ & $\begin{array}{l}\text { Reinhold Fabritius (x) } \\
\text { Joathan Collander } \\
\text { Karl Ahlberg (x) } \\
\text { Oskar Lilius (veo) }\end{array}$ \\
\hline 1874 & & $\begin{array}{l}\text { Gunnar Berndtson } \\
\text { Ernst Nordström }\end{array}$ & Eliel Aspelin & $\begin{array}{l}\text { Emil Waldermar } \\
\text { Cedercreutz (veo) } \\
\text { Karl Fredrik Slotte (x) }\end{array}$ \\
\hline 1885 & Kustaa Edvard Asp & $\begin{array}{l}\text { Agathon Reinholm } \\
\text { Kaarlo Vuori }\end{array}$ & Emil Nervander & \\
\hline 1887 & $\begin{array}{l}\text { Karl Gustaf Grahn } \\
\text { Selim Lindqvist }\end{array}$ & Agathon Reinholm & Emil Nervander & \\
\hline 1892 & $\begin{array}{l}\text { Selim Lindqvist } \\
\text { Lars Sonck } \\
\text { Jarl Stolpe (Y) }\end{array}$ & & $\begin{array}{l}\text { Alfred Hackman (veo) } \\
\text { Emil Nervander }\end{array}$ & \\
\hline 1896 & $\begin{array}{l}\text { Armas Lindgren } \\
\text { Viktor Sucksdorff (Y) } \\
\text { Aksel Wikström }\end{array}$ & & $\begin{array}{l}\text { Emil Nervander } \\
\text { (Alfred Hackman veo) }\end{array}$ & \\
\hline 1899 & $\begin{array}{l}\text { Jarl Eklund } \\
\text { Carl Frankenhaeuser } \\
\text { (veo) }\end{array}$ & & $\begin{array}{l}\text { Björn Cederhvarf } \\
\text { Karl Konrad Meinander } \\
\text { Emil Nervander }\end{array}$ & \\
\hline 1902 & $\begin{array}{l}\text { Jarl Eklund }(Y) \\
\text { Carl Frankenhaeuser } \\
\text { Armas Lindgren }\end{array}$ & & Karl Konrad Meinander & \\
\hline
\end{tabular}

aikataulu oli kireä ja dokumentoinnin tahti rivakka. Vuoden 1892 retkestä lähtien yhden osallistujan tuli osata myös valokuvata. Arkkitehdit olivat tärkeitä, koska heidän koulutuksensa antoi valmiudet sekä rakennusten luotettavaan mittaamiseen, tulosten kuvalliseen esittämiseen että hyvään piirtämiseen. Tutkijoita tarvittiin tunnistamaan ja arvioimaan kuvattavia kohteita. Suuri osa retkeläisistä oli opiskelijoita, joista myöhemmin valmistui arkkitehteja, taiteilijoita ja tutkijoita. Retken johtaja oli aina tutkija ja hänellä oli päävastuu yhdistyksen johtokunnalle esitettävän matkakertomuksen laatimisesta.

Ehdokkaista ei ollut ylitarjontaa, eikä yhdistys voinut muovata retkikuntaa osallistujia valitsemalla. Osallistujista voi siten päätellä keitä retket kiinnostivat ja miten kiinnostuneisuus muuttui kolmen vuosikymmenen aikana. Arkkitehti-taiteilija-tutkija -jaottelun ulkopuolelle sijoittuvia "muita" osallistui vain kahdelle ensimmäiselle retkelle. Taiteilijoita ei ollut mukana enää 1890-luvulta lähtien.

Asetelma. Olen luokitellut osallistujat tulevan ammatin perusteella. Merkintä x tarkoittaa, että henkilö oli retkellä piirtäjänä, mutta teki uransa muulla alalla kuin taulukossa mainitut arkkitehdit, taiteilijat tai tutkijat. Merkintä $Y$ tarkoittaa arkkitehdin osallistuneen retkelle Yleisten rakennusten ylihallituksen kustannuksella. Veo-merkintä tarkoittaa henkilön osallistuneen retkelle vapaaehtoisena ja vain osan matkaa. taiteen kultakauden maineikas kansallisromanttinen kiinnostus kansaa ja kotimaata kohtaan ei saanut taiteilijoita osallistumaan yhdistyksen taidehistoriallisiin tutkimusretkiin. Taiteen vapautta korostaneille, 


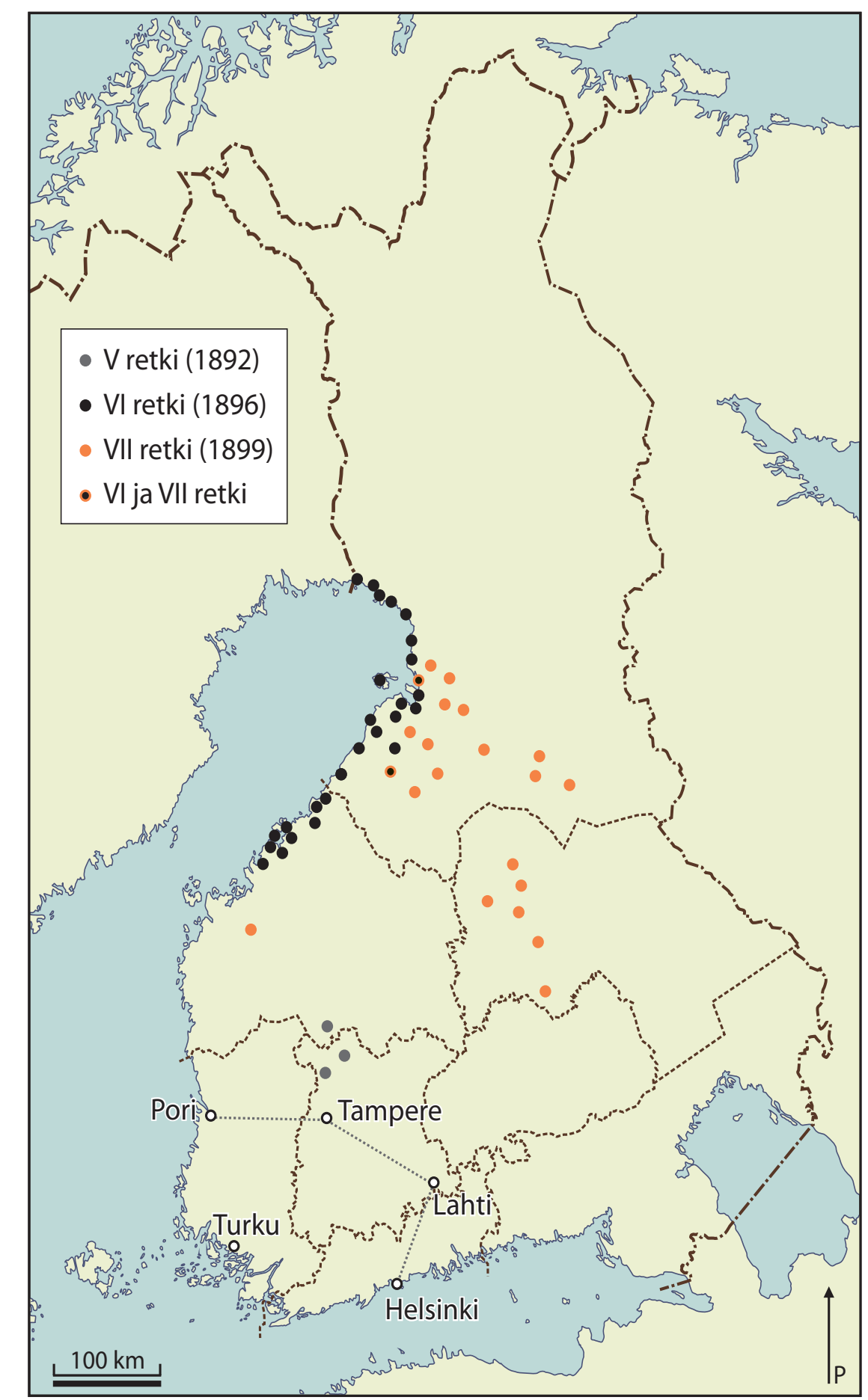

Kuva 1. Kartta Suomen Muinaismuistoyhdistyksen taidehistoriallisten tutkimusretkien kartoittamista alueista. Karttaan on merkitty Suomen Suuriruhtinaskunnan ja läänien rajat. Retket painottuivat länteen ja erityisesti lounaiseen Suomeen. Retket I-V ja VIII kulkivat alueella, joka mantereen osalta mahtuu Porista Tampereelle, Lahteen ja Helsinkiin vedetyn linjan sisälle. Lisäksi tutkittiin Turun saaristo ja Ahvenanmaa. Viidennen retken Tampereelta käsin tehty käynti Virroilla, Ruovedellä ja Kurussa on merkitty karttaan mukaan. Kuudes ja seitsemäs retki suunnattiin Pohjanmaalle, Pohjois-Savoon ja Kainuuseen, reitit ristesivät Oulussa ja Oulaisissa. Kartta: Hannu Linkola. henkilö- ja maisemakuvaukseen keskittyneille kuvataiteilijoille Länsi-Suomen vanhan taiteen dokumentointi ei ehkä ollut tarpeellinen ansio tai varsinkaan houkuttelevana tilaisuus, retkellä kun piti työskennellä ryhmässä nopeasti ja kurinalaisesti.

Sen sijaan arkkitehtien aktiivisuus kasvoi selvästi. Tähän vaikutti ehkä 1800-luvun lopun arts-and-crafts -liike ja arkkitehtien toimenkuvan laajentuminen käsittämään rakennussuunnittelun lisäksi myös kokonaisvaltaisen sisustuksen suunnittelun, siis taideteollisuuden aluetta. Tutkimusretkillä työskentely ja kotimaan kirkkoarkkitehtuurista ja -interiööreistä ammennettava tieto ja vaikutelmat palvelivat arkkitehtien tarpeita. Retkillä saatu dokumentointitaito ja vanhan arkkitehtuurin tuntemus oli arkkitehdille myös meriitti, jonka saattoi sisällyttää ansioluetteloon.

Ensimmäinen retki oli Emil Nervanderin (1840-1914) idea, hänen helmikuussa 1871 yhdistyksessä tekemänsä ehdotus sai aikaan vilkasta keskustelua ja ennen kaikkea ripeää toimintaa. Retkelle asetettiin moninaisia tavoitteita, tuli dokumentoida sekä erilaisia taidehistoriallisesti kiinnostavia esineitä että aineetonta kulttuuria kuten kansan 
kertomuksia. Keskiaikaiset kirkot ja varsinkin keskiaikaiset puuveistokset hahmotettiin kaikkein uhanalaisimmiksi ja kiireimmin dokumentoitaviksi kohteiksi, joten niiden asema tutkimuskohteina korostui. Tärkeimmän tehtävän eli dokumentoinnin katsottiin hyödyttävän tutkijoita, taiteilijoita ja yleisöä. ${ }^{5}$

Retkikunnan johtajaksi pyydettiin ruotsalainen taiteilija Nils Månsson Mandelgren (1813-1899), jolla oli kiistaton maine muinaismuistojen dokumentoijana. ${ }^{6}$ Hän liittyi retkikuntaan vasta Ahvenanmaalla, eikä hän nähtävästi onnistunut saavuttamaan toivottua arvonantoa muun retkikunnan silmissä. ${ }^{7}$ Retken todellinen johtaja oli filosofian kandidaatti Nervander, joka oli mukana koko retken ajan, kokosi ja kirjoitti retken kertomuksen ja järjesti tuloksista näyttelyn.

Ensimmäinen retkikunta oli kaikkein suurin, vaikka useat osallistujat olivat mukana vain osan matkaa. Retki kesti kaksi ja puoli kuukautta kesäkuun puolivälistä elokuun loppuun. ${ }^{8}$ Osallistujat olivat johtajia lukuun ottamatta hyvin nuorta väkeä: ylioppilaat Karl Ahlberg (1849-?'), Eliel Aspelin (18471917), Jonathan Collander (1850-1942), Albert Edelfelt (1854-1905), Fredrik Fabritius (1850-1919) ja Oskar Lilius (1848-1913)

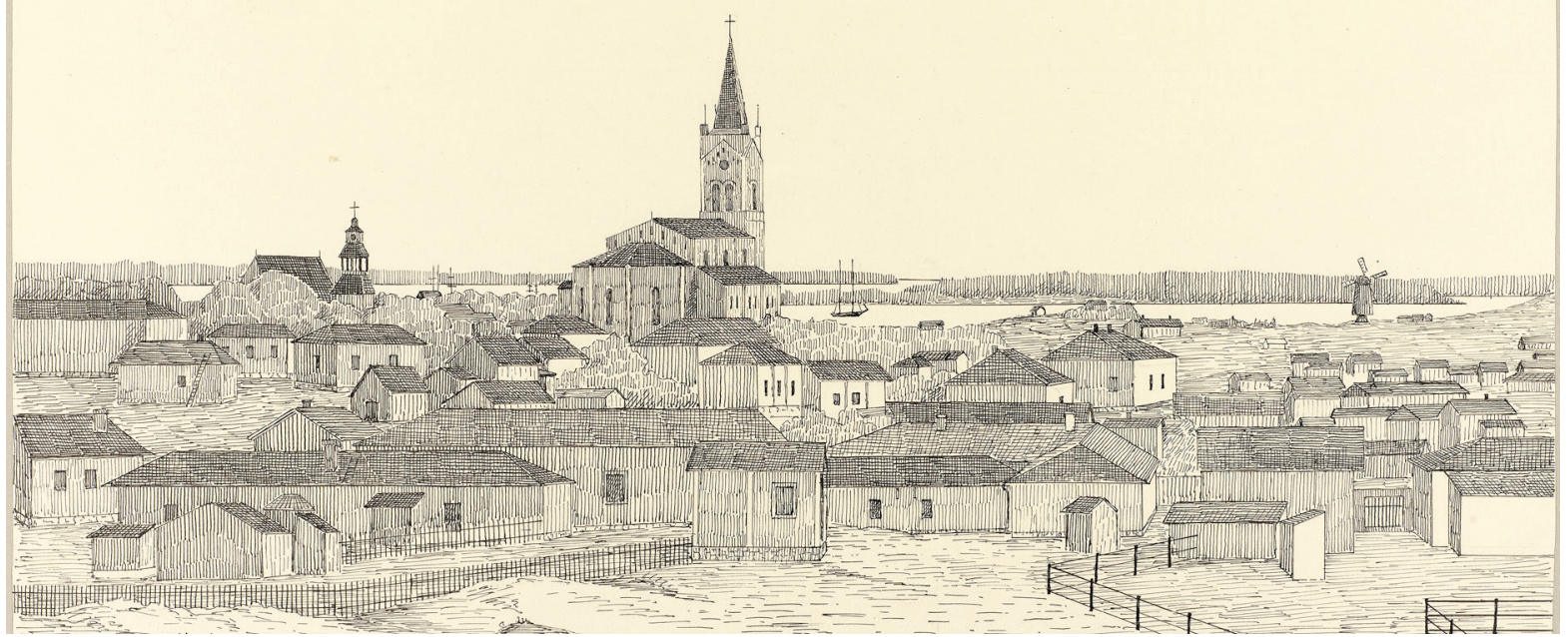

Kuva 2. Ernst Nordström, Näkymä Uuteenkaupunkiin, 10.7.1874. Piirustus, 32,5 x 49,9 cm. Nordström teki retkellä ainakin viisitoista maisemia ja rakennettua miljöötä kuvaavaa piirustusta. Nämä kuvat eivät olleet mukana retkikunnan kuvien näyttelyssä syksyllä 1874, eivätkä ne ole retken kuvaluettelossa. Syynä saattoi olla hänen käyttämänsä piirustustyyli, jota ei ehkä pidetty tarpeeksi dokumentaarisena. Museoviraston kuvakokoelmat, Historian kuvakokoelma, Helsinki.

sekä arkkitehti Wolmar Westling (18451881). Ensimmäisen retkikunnan reitti oli seuraava:

Taalintehdas, Västanfjärd, Dragsfjärd, Kemiö, Sauvo, Karuna, Parainen, Kakskerta, Turku, Degerby, Maarianhamina, Lemland, Joma- la, Lemböte, Hammarland, Eckerö, Geta, Finström, Saltvik, Sund, Vårdö, Lumparland, Föglö, Degerby, Kökar, Sottunga, Kumlinge, Lappo, Houtskari, Korppoo, Nauvo, Turku, Kaarina, Maaria, Naantali, Taivassalo, Askainen-Louhisaari, Nousiainen, Masku, Turku. 
Nervander kuvasi retken Hufvudstadsbladetissa 1871-1872 ilmestyneissä matkakirjeissä. ${ }^{10}$ Retkikunta kulki jalan ja hevosrattailla, saaristossa purjeveneillä ja soudettuina. Kohteista huippuina erottuivat Kumlingen ja Taivassalon kirkkojen seinämaalaukset, joita dokumentoitiin huolella ja aikaa käyttäen. ${ }^{11}$ Retken yllätyksiin kuuluivat muun muassa Nousiaisten kirkko ja Pyhän Henrikin sarkofagi, joka sai lyhyeksi "turistikäynniksi" aiotun vierailun venymään. ${ }^{12}$ Ylipäätään retken suuri sato ja löydettyjen kohteiden laatu vaikutti olleen yllätys sekä yhdistykselle että yleisölle.

\section{Toinen retki 1874}

Seuraavaa retkeä suunniteltaessa päädyttiin ohjelmasta karsimaan pois aikaa vievät ja huomiota hajottavat arkistotutkimukset ja kansanperinteen kerääminen. Osallistujamäärä supistettiin neljään. ${ }^{13}$ Yhdistys pyrki hankkimaan kameran, mutta sen rahavarat olivat niin niukat, ettei Aspelinin selvitysten mukaan kemikaaleineen noin 500-600 markkaa maksavaa laitetta voitu ostaa. ${ }^{14}$

Aspelinia lukuunottamatta olivat edellisen retken osallistujat hajaantuneet muualle ja muihin tehtäviin. ${ }^{15}$ Hän ryhtyi filosofian mais- teri Karl Fredrik Slotten (1848-1914) ja ylioppilaiden Gunnar Berndtsonin (1854-1895) ja Ernst Nordströmin (1850-1933) muodostaman retkikunnan johtajaksi. Mukaan ei saatu arkkitehtiä, joten tarkempi arkkitehtuurin tutkimus jätettiin pois ohjelmasta. ${ }^{16}$ Ryhmä koostui hyvistä piirtäjistä, sillä Slotte oli tulevasta fyysikon urasta huolimatta tunnettu piirustus- ja maalausharrastuksestaan, Berndtson kouluttautui retken jälkeen taiteilijaksi ja Nordström taas suuntautui taideteollisuuteen. ${ }^{17}$ Ylioppilas Emil Waldermar Cedercreutz (1852-1924) osallistui retkeen Turusta Mynämäelle ja teki sen omalla kustannuksellaan. ${ }^{18}$

Toinen retki kesti hieman vajaat kaksi kuukautta alkaen 8. kesäkuuta ja jatkuen heinäkuun loppuun. Se kartoitti noin 40 kilometriä rannikosta sisämaahan ulottuvan vyöhykkeen Turusta Poriin.

Turku, Raisio, Masku, Rusko, Lemu, Askainen, Merimasku, Rymättylä, Askainen-Louhisaari, Mietoinen, Mynämäki, Vehmaa, Lokalahti, Uusikaupunki, Kalanti, Laitila, Untamala, Pyhäranta, Pyhämaa, Rauma, Eurajoki, Lappi, Hinnerjoki, Eura, Kauttua, Köyliö, Ulvila, Pori.
Matkan huippuja olivat Mynämäen kirkko, Askaisten kirkko ja erityisesti sen saarnatuoli, Louhisaaren kartanolinna ja Vehmaan alttarikaappi. Kalannin alttarikaappi sai paljon huomiota, mutta herätti myös hämmennystä. ${ }^{19}$ Louhisaaressa retkikunta kävi kahteen kertaan, kuvasi antaumuksella sen isännän keräämiä esineitä sekä pääsi vieraanvaraisen isäntäparin mukana vierailemaan lähistön kartanoihin ja huviloihin.

Retkestä on olemassa useiden henkilöiden kirjoittamia kuvauksia. Helsingfors Dagbladissa ilmestyi anonyymin kirjoittajan koko matkan kattavat matkakirjeet, Morgonbladetissa Eliel Aspelinin Uuteenkaupunkiin asti pääsevät matkakirjeet ja Ảbo Postenissa Aspelinin täydentävä matkakirje sekä Nervanderin hänelle annettuihin tietoihin perustuvat matkakirjeet. ${ }^{20}$ Toisen retkikunnan Aspelinin ja Cedercreutzin kirjoittamista osuuksista koostuva kertomus on sekava. Kertomuksesta puuttuu kuvaluettelo, joten retkellä tehdyistä dokumentoinneista on olemassa vain tutkimusretken jälkeen järjestetyn näyttelyn luettelo. ${ }^{21}$

\section{Kolmas retki 1885}

Kolmas tutkimusretki järjestettiin yhdentoista vuoden kuluttua edellisestä. Syitä näin 
pitkään taukoon löytyy useita. Toisen retkikunnan järjestäminen ja ensimmäisen Aikakauskirjan painattaminen ajoivat yhdistyksen kassan miinukselle. ${ }^{22}$ Syksyllä 1875 havaittiin väärinkäytöksiä yhdistyksen kirjanpidossa ja se kärsi rahavaroihinsa nähden tuntuvan tappion. ${ }^{23}$ Myös retkien johtaja puuttui. Nervander asui vuoden 1879 loppuun Turussa ja keskittyi Helsinkiin palattuaan Ensimmäisen suomalaisen taideteollisuusnäyttelyn järjestämiseen vuosina 1880 ja $1881 .{ }^{24}$ Kun vuonna 1882 ehdotettiin uuden retken järjestämistä, ei kukaan aikaisemmin osallistunut ryhtynyt sen johtajaksi. ${ }^{25}$

Vuonna 1884 Yhdistyksen taloudellinen tilanne parani ratkaisevasti, sillä se sai liikemies Gustaf Fredrik Ahlgrenin testamentilla huomattavan lahjoituksen. ${ }^{26}$ A. M. Tallgren esitti myöhemmin retkien jatkamisen syyksi Muinaistieteellisen Toimikunnan perustamisen. Toimikunta tarvitsi Yhdistyksen retkiä pohjakseen, koska sen oli mahdotonta toimia ilman tietoja "historianaikuisista muinaisjäännöksistä". ${ }^{27}$ Yhdistys siis nähtiin uuden, 1880-luvulla annettujen asetusten nojalla toimivan, Muinaistieteellisen toimikunnan tiedonkerääjänä. Tallgrenin mukaan Nervan-

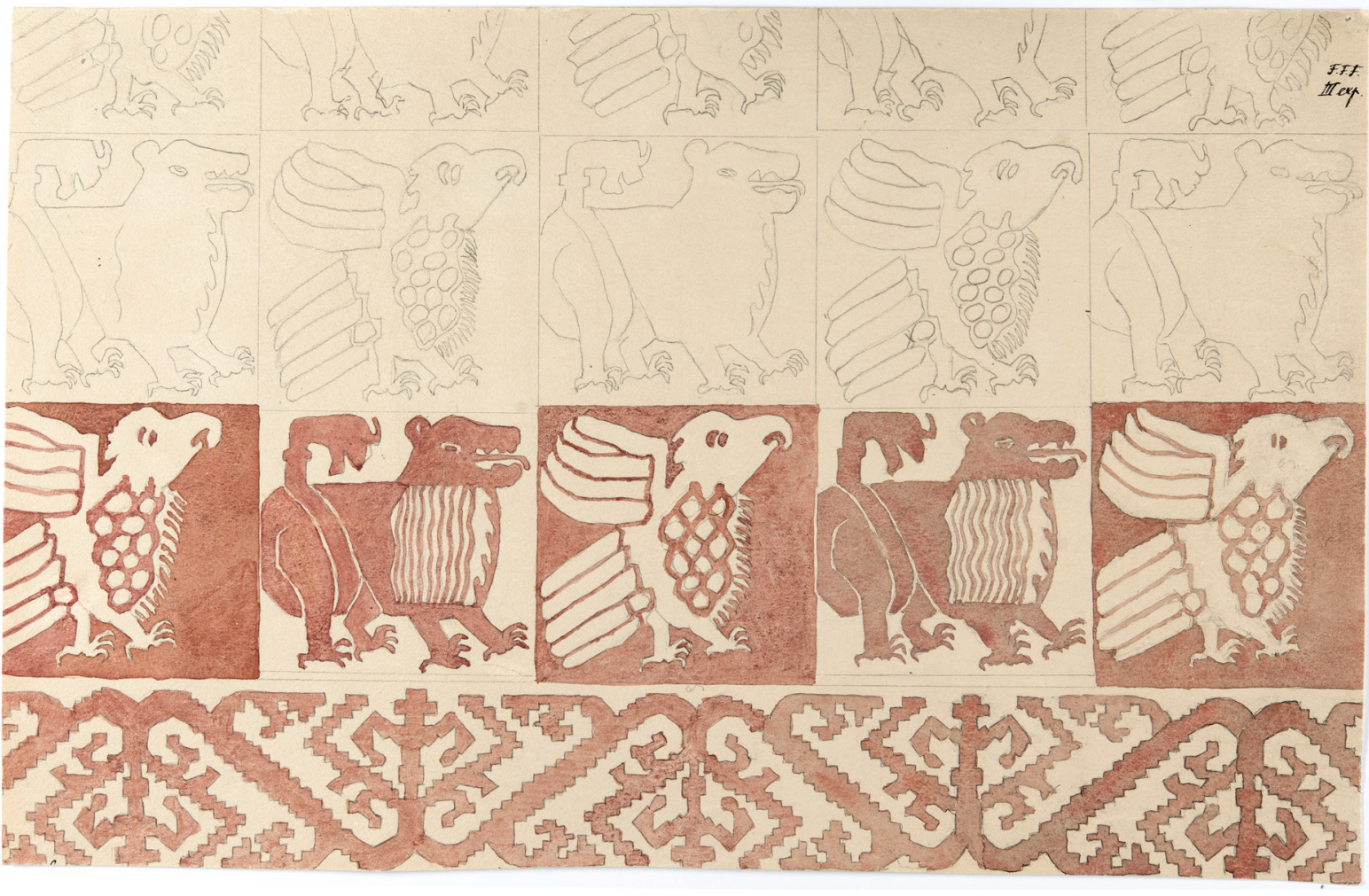

Kuva 3. Kaarlo Vuori, Marttilan täkänä (retken kuvaluettelossa: S:t Mårtens, Dubbelväfnad: bönpallsbeklädnad), 1885. Piirustus ja akvarelli, $22 \times 33 \mathrm{~cm}$. Poikkeuksellisesti kuvaan ei ole oikean yläkulman "F.F.F. III exp." -tunnisteen lisäksi merkitty muita retken tietoja. Kuvan tekijä on nimetty retken kertomuksen kuvaluettelossa. Tekstiilejä dokumentoitaessa piti päättää asetetaanko pääpaino kuva-aiheelle, materiaalin tunnulle vai esimerkiksi ommelten esittämiselle. Museoviraston kuvakokoelmat, Historian kuvakokoelma, Helsinki. 
der myös pelkäsi, että retkien järjestämisessä jo hankittu käytännön taito katoaisi mitä kauemmin aikaa kuluisi ja retkien "alkuunpanijat vanhenivat ja vetäytyivät syrjään"28.

Seuraavan kerran retkeä ehdotti Nervander toukokuussa $1885 .{ }^{29}$ Hän oli hankkinut ensimmäisen retken jälkeen runsaasti asiantuntemusta ja kokemusta ja ryhtyi johtamaan retkeä. ${ }^{30}$ Kolme muuta jäsentä olivat ensikertalaisia, mutta muodostivat tiiviin rutinoituneiden piirtäjien joukon. Kustaa (Gustaf) Edvard Asp (1866-1952) valmistui arkkitehdiksi retkeä seuraavana vuonna, Agathon Reinholm (1857-1887) oli dokumentointiin ja tutkimusretkiin erikoistunut taiteilija ja Kaarlo Vuori (1863-1914) taideopiskelija. ${ }^{31}$

Retki kesti kaksi kuukautta kesäkuun toisesta päivästä elokuun alkuun. Liikkeelle lähdettiin Lohjan kirkosta, jossa työskenneltiin kaksi viikkoa. Retkikunta tutki melko suppean maantieteellisen alueen, mutta tuloksena oli 451 kuvaa. ${ }^{32}$ Reitti kulki seuraavasti:

Lohja, Mustio, Karjaa, Tammisaari, Pohja, Fiskars, Tenhola, Bromarv, Särkisalo, Perniö, Koski, Yliskylä, Salo, Uskela, Halikko, Angelniemi, Teijo, Turku, Aura, Lieto, Piikkiö, Kuusisto, Paimio, Tarvasjoki, Karinainen, Marttila, Kos- ki T1, Kuusjoki, Pertteli, Muurla, Kisko, Karjalohja, Sammatti, Lohja.

Retken kertomus poikkeaa kahdesta edellisestä, sillä se on kokonaan retken johtajan kirjoittama ja etenee järjestyksessä kohteelta toiselle reitin mukaan. Kuvaluettelossa ja matkakirjeissä huomiota kiinnittää kuvien tekeminen paikoissa, jotka mainitaan vähemmän kiinnostaviksi. Kolmannesta retkestä lähtien kaikki kirkot tutkittiin tarkasti. Myös uudempi esineistö käytiin läpi ja luetteloitiin, joten kertomukseen tuli inventaarinomaista sävyä. Erityisen tarkasti merkittiin muistiin kaikki esineisiin ja kuviin liittyvät tekstit. Retkeä sävyttivät useat vaikutusvaltaisten aatelissukujen suuret kartanot, joiden kustaviaaniseen ja Suomen sotaan liittyvään historiaan Nervander upposi matkakirjeissään. Retkestä ilmestyi kaksi matkakirjesarjaa, Nervanderin kirjeet Hufvudstadsbladetissa ja Uudessa Suomettaressa anonyymin kirjoittajan kirjeet. ${ }^{33}$

Retken yllätyksiä olivat Karjaan kirkon holvien päältä löytynyt Pietà-veistos ja monet kirkkorakennusta vanhemmat esineet. Aikaisemmilla retkillä oli huomattu, että keskiaikaisia esineitä saattoi löytyä muualtakin kuin keskiaikaisista kirkoista. Esimerkiksi 1700-luvulla rakennetusta Marttilan kirkosta tavattiin kangas, johon oli kudottu "kömpelöitä punaisen ja valkoisen värisiä jalopeurain ja kotkain kuvia." ${ }^{34}$

\section{Neljäs retki 1887}

Neljättä retkeä ehdotti Nervander helmikuussa 1887 ja häntä pyydettiin sen johtajaksi. ${ }^{35}$ Nervander oli ehtinyt edellisen tutkimusretken jälkeen pätevöityä huomattavasti erityisesti keskiajan tutkimuksessa. ${ }^{36}$ Muut jäsenet olivat dokumentointiin perehtyneenä ammattimiehenä arvostettu Agathon Reinholm ja polyteknikot Karl Gustaf Grahn (1868-1907) ja Selim Lindqvist (1867-1939). ${ }^{37}$ Retki kesti kaksi kuukautta ja sen reitti oli seuraava:

Tuusula, Nurmijärvi, Hausjärvi, Janakkala, Renko, Vanaja, Hattula, Tyrväntö, Sääksmäki, Kalvola, Akaa, Kylmäkoski, Urjala, Humppila, Loimaa, Metsämaa, Alastaro, Vampula, Huittinen, Kokemäki, Harjavalta, Kiukainen, Eura, Säkylä, Virttaa, Oripää.

Neljäs retki on ainoa, josta ei ole olemassa julkaistua tekstiä edes osalta matkaa, eikä sen olosuhteista ja tunnelmasta siten ole 

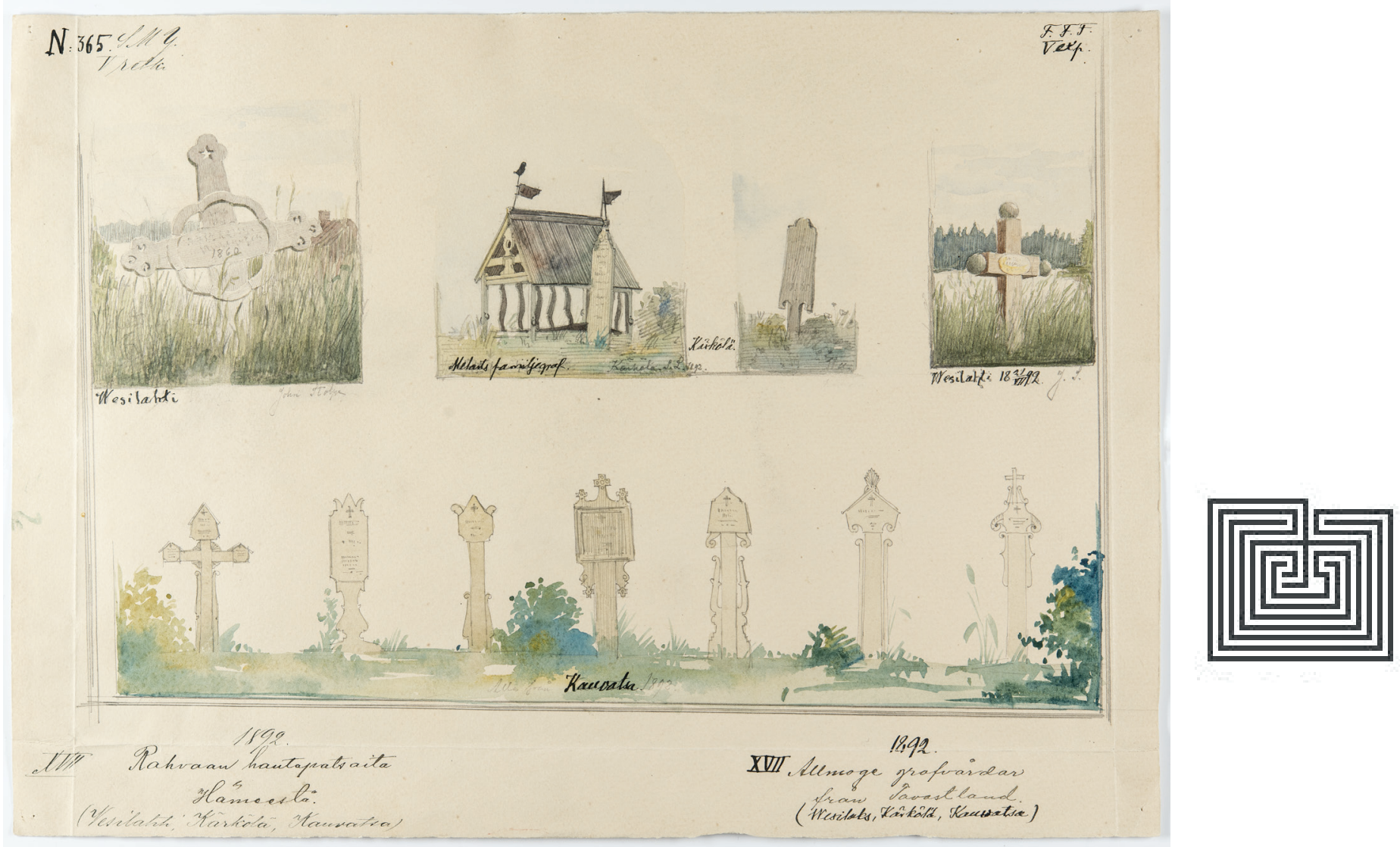
mentointeja. Dokumentointien erikoisuus oli Lindqvistin tekemän akvarelli Ritvalan helkajuhlan viettopaikasta, vastaavaa toista kansantraditioon liittyvän paikan dokumentointia ei retkikuvien kokonaisuudessa ole.

\section{Viides retki 1892}

Viidettä retkeä edelsi kaksi Nervanderin ehdotusta vuosina 1888 ja 1891, joihin kumpaankaan Muinaismuistoyhdistys ei katsonut voivansa varojen niukkuuden vuoksi suostua. ${ }^{39}$ Vuonna 1892 järjestämiseen ryhdyttiin. Ryhmässä oli taas neljä jäsentä, johtajana Nervander ja kolme erityisesti arkkitehtuurin kuvaamiseen sopivaa henkilöä, jo kerran

Kuva 4. Rahvaan hautapatsaita Hämeestä. Vesilahti, Kärkölä, Kauvatsa, 1892. Akvarelli, $28 \times 38 \mathrm{~cm}$. Ylärivin reunimmaisissa kuvissa on John Stolpen signeeraus, keskimmäisessä Selim Lindqvistin. Akvarellin yläkulmiin on merkitty yhdistyksen lyhenne ja retken järjestysnumero, vasemmalla oleva N:365 on kuvan järjestysnumero retken kuvaluettelossa. Alalaidassa on retken vuosiluku, kuvan aihe ja paikkakunta. Retkillä tehdyille rahvaan hautojen dokumentoinneille on tyypillistä anonyymiys, haudat edustavat aluetta, eikä haudattua henkilöä tai sukua mainita toisin kuin ylempien säätyjen hautojen dokumentoinneissa. Haudat eivät olleet kovin vanhoja, joten muinaismuistoarvoa enemmän niissä tuntui kiinnostavan hautausmaakulttuuri ja kansanomainen muodonanto. Museoviraston kuvakokoelmat, Historian kuvakokoelma, Helsinki. 
mukana ollut arkkitehti Selim Lindqvist, arkkitehti John Stolpe (1863-1939) ja polyteknikko Lars Sonck (1870-1956)..$^{40}$ Stolpe oli mukana Yleisten Rakennusten Ylihallituksen määräämänä arkkitehtinä, jollainen nyt pitkän tauon jälkeen taas saatiin. ${ }^{41}$ Arkeologiaan erikoistuva Alfred Hackman (1864-1942) osallistui retkeen Ruovedelle asti ja teki sen omalla kustannuksellaan. ${ }^{42}$

Ensimmäistä kertaa mukana ollutta "valokuvauskojetta" käyttivät Lindqvist ja Hackman. ${ }^{43}$ Kertomuksen kuvaluettelossa mainitaan myös otetut valokuvat. Valokuvaus ei korvannut aikaisempia menetelmiä vaan tuli lisätekniikaksi niiden rinnalle.

Retki kesti kaksi kuukautta kesäkuun puolivälistä elokuun puoliväliin. Se kulki laajan kaaren Mäntsälästä Hollolan kautta Tampereelle, teki sieltä silmukan Virroille, ja jatkoi Tampereelta kohti länttä Huittisiin asti.

Järvenpää, Mäntsälä, Orimattila, Nastola, Lahti, Hollola, Kärkölä, Hämeenkoski, Lammi, Tuulos, Hauho, Pälkäne, Kangasala, Messukylä, Tampere, Virrat, Ruovesi, Kuru, Tampere, Lempäälä, Vesilahti, Pirkkala, Nokia, Tottijärvi, Suoniemi, Karkku, Tyrvää, Sammaljoki, Kiikka, Keikyä, Kauvatsa, Huittinen.
Aikaisemmissa suunnitelmissa Nervander suuntasi reitin kaartumaan Itä-Hämeeseen ja Itä-Uudellemaalle, mutta toteutettu retki kuitenkin kulki kohti länttä. ${ }^{44}$ Reitti oli pitkä ja sisälsi vaihtelevia kohteita keskiaikaisista kirkoista kartanoihin ja talonpoikaistaloihin. Vesilahden ja Nokian seuduilla kartanoiden osuus retkessä korostui. Nervander julkaisi pitkän matkakirjesarjan Hufvudstadsbladetissa. ${ }^{45}$ Niistä käy ilmi, että Tampereelta käsin höyrylaivalla tehty retki Virroille, Ruovedelle ja Kuruun oli pettymys. Kirkoissa oli hyvin vähän esineistöä, eikä pelkkä puukirkkojen arkkitehtuuri sytyttänyt retkikuntaa. Toisaalta monin paikoin, esimerkiksi Vesilahdella ja Hollolassa, "saalis" oli odottamattoman hyvä.

Matkakirjeissä korostui ruokailun, sen järjestämisen ja ruuan laadun merkitys. Hyvyydellä ei aina tarkoitettu makua vaan monipuolisuutta. Ongelma oli aito, sillä alkukesän sateisuus aiheutti todellista ruokapulaa ja sen lisäksi vaikeutti matkantekoa.

\section{Kuudes retki 1896}

Vuonna 1894 Nervander ehdotti retkeä joko Kokemäenjoelta pohjoiseen tai Hanko-Hyvinkää -radan itäpuolelle. Ensimmäinen vaihtoehto olisi jatkanut toisen retken suuntaa pitkin länsirannikkoa, jälkimmäinen aloittanut kolmannen retken lähtöpisteestä mutta edennyt päinvastaiseen suuntaan. ${ }^{46}$ Vuonna 1896 toteutettu retki avasi edellisiin suunnitelmiin nähden aivan uuden alueen ja tutki Pohjanmaan rannikkoa Uudestakaarlepyystä pohjoiseen. Tärkein tavoite oli etsiä Mikael Toppeliuksen töitä ja selvittää oliko ollut olemassa erityinen oulumaalareiden ryhmä. Erityisenä puoltavana perusteena käytettiin Toppeliuksen sukulaisuutta yhdistyksen ensimmäiseen puheenjohtajaan Zachris Topeliukseen. ${ }^{47}$ Vaikka maalaustaidetta korostettiin, tultiin nyt aloittaneeksi myös määrätietoinen puukirkkoarkkitehtuurin tutkimus.

Kuudetta retkeä johti Nervander, piirtäjinä olivat polyteknikko Armas Lindgren (1874-1929), arkkitehti Axel Wikström (1869-1901) ja Yleisten rakennusten ylihallituksen lähettämä arkkitehti Viktor Sucksdorff (1866-1952). ${ }^{48}$ Yksi lehtijuttu mainitsee osallistujaksi myös Alfred Hackmanin. ${ }^{49}$ Valokuvaamisesta vastasivat Lindgren ja Sucksdorff, jolla jälkimmäisellä oli kertynyt kokemusta Karjalaan suuntautuneelta tutkimusretkeltä. ${ }^{50}$ Kaikki olivat taitavia dokumentoijia, erityisesti monet Lindgrenin piirroksis- 
ta ja akvarelleista ovat taidehistoriallisten tutkimusretkien sykähdyttävimpiä.

Kaksi kuukautta kestänyt retki kulki Oulaista ja Vihantia lukuun ottamatta kapeaa rannikkokaistaa:

Uusikaarlepyy, Pietarsaari, Kruunupyy, Kokkola, Kälviä, Lohtaja, Himanka, Kalajoki, Pyhäjoki, Oulainen, Vihanti, Raahe, Saloinen, Siikajoki, Hailuoto, Revonlahti, Liminka, Kempele, Oulu, Haukipudas, Ii, Kuivaniemi, Simo, Kemi, Keminmaa, Tornio.

Retkikunnan etenemistä leimasi tiukka aikataulu. Työtä tehtiin joka päivä, sillä sunnuntait käytettiin paikasta toiseen siirtymiseen, pohjapiirrosten työstämiseen sekä piirustusten tarkistamiseen ja täydentämiseen kun niiden kohde oli vielä tuoreessa muistissa. ${ }^{51}$ Nervander sai kirjoitettua vain kaksi alkumatkaa kuvaavaa matkakirjettä. Näiden Kesämatkoja Suomessa-kirjeiden perusteella voi päätellä, että retkessä oli ensimmäisen retken tapaista pioneerihengen ja löytämisen riemun tunnelmaa. ${ }^{52}$ Matkakirjesarjan keskeneräisyyden vuoksi emme tiedä minkälaisia reaktioita huippulöydöt kuten Saloisten, Hailuodon, Kempeleen ja Haukiputaan puisten tukipilarikirkkojen suuret seinämaalaussarjat tai Saloisten kirkon keskiaikaiset alttarikaapit aiheuttivat. Retkikertomuksessa kohteiden arvostus ja kehittyneet työtavat näkyvät huolellisena paneutumisena kohteisiin. Esimerkiksi Saloisten seinämaalaukset kuvailtiin kiireestä huolimatta kuva kerrallaan ja ne sijoitettiin kirkon pohjakaavaan. Alttarikaapin kuvaamisen tarkkuus ja kattavuus olivat aivan toista luokkaa kuin esimerkiksi 1874 Kalannin alttarikaappia dokumentoitaessa. ${ }^{53}$

Retkikertomukseen liitetty kuvaluettelo on keskeneräisen oloinen, sekin kuin kiireessä tehty, ja täynnä Nervanderin myöhemmin tekemiä paikkamerkintöjä. Hän mainitsi retkikertomuksen kokoamisen työläydestä seuraavan retken suunnitelmassa, pelkkä vuoden 1896 kertomuksen koostamiseen oli vaatinut kaksi kuukautta. ${ }^{54}$

Kuudennelta retkeltä on peräisin kolme ehkä useimmin eri yhteyksissä toistettua kuvaa: Armas Lindgrenin akvarelli Saloisten tukipilarikirkon maalauksin koristetusta interiööristä ja kaksi tutkimusretkikuntien työtä harvinaisella tavalla dokumentoivaa valokuvaa. Toisessa niistä on menossa evästauko Kempeleen kirkossa ja toisessa piirretään
Keminmaan kirkon kattomaalauksia heinäkasassa maaten. Tältä retkeltä on myös poikkeuksellinen kuvaus valokuvaamisen ongelmista: mukaan otetut kaksi "valokuvauskonetta" olivat käyttäjilleen tuntemattomia, joten niihin piti tutustua retken alussa, ja valokuvaajilla oli myös vaikeuksia löytää tarvittavia "pimeitä paikkoja valonaroille laatoille". ${ }^{5}$

\section{Seitsemäs retki 1899}

Kuudes retki oli selvästi menestys ja Nervander ryhtyi heti järjestämään uutta, nyt Oulun rautatiestä itään. ${ }^{56}$ Rahoitus saatiin järjestymään, sillä Yhdistys sai Längmanin rahoista 3000 markkaa. Ongelmaksi muodostui se, ettei Yleisten Rakennusten Ylihallitus enää myöntänyt arkkitehtiaan mukaan eikä Nervanderin mielestä retkeä voitu panna toimeen ilman arkkitehtia. Lopulta retki onnistui Yhdistyksen myöntämällä lisärahoituksella.57 Matkaan lähtivät Nervanderin lisäksi keskiaikaisiin puuveistoksiin erikoistuva maisteri Karl Konrad Meinander (1872-1933), juuri valmistuva arkkitehti Jarl Eklund (1876-1962) ja ylioppilas Björn Cederhwarf (1876-1960). Osaksi matkaa mukaan lähti vielä vapaaehtoisena arkkitehti Carl Frankenhaeuser (1878-1962). ${ }^{58}$ 
Retki kesti puolitoista kuukautta kuudennesta kesäkuuta heinäkuulle ${ }^{59}$.

Kuopio, Leppävirta, Maaninka, Pielavesi, Iisalmi, Lapinlahti, Sotkamo, Kajaani, Paltaniemi, Säräisniemi, Utajärvi, Muhos, Oulu, Kiiminki, Ylikiiminki, Oulu, Ruukki, Paavola, Rantsila, Pulkkila, Haapavesi, Oulainen, Isokyrö.

Tavattoman laajan alueen tutkimisen mahdollistivat rautatieyhteyksien, höyrylaivojen ja Oulunjoen jokireitin käyttö. ${ }^{60}$ Suuri osa matkasta taitettiin hevosrattailla. Retken alkupuolta leimasi myöhäinen vuodentulo, tulvat ja katovuoden pelko. Retkikunta onnistui löytämään paljon Toppeliuksen tekemiksi tunnistamiaan töitä, tosin myös tietoja 24:stä aivan lähivuosina tuhotusta maalauksesta. ${ }^{61}$ Tämä lisäsi retkikunnan tuntemusta työnsä tärkeydestä, he juoksivat kilpaa ajan kanssa. Jos Nervanderin hyväntuuliseen kuvaukseen Nuori Suomi -albumissa vuonna 1899 on uskominen, oli retkikunnan työskentely sujuvaa ja henki hyvä. Se pystyi kuljetun matkan pituudesta huolimatta tuottamaan paljon kuvia ja tekemään tiiviisti työtä lyhyessä ajassa, mikä kuvaa osallistujien asiantuntevuutta.
Seitsemäs retki oli Nervanderin viimeinen yhdistyksen puitteissa. Hän todennäköisesti koki saaneensa akateemiseen tutkimukseen suuntautuneesta ja keskiaikaan perehtyneestä Meinanderista toivomansa jatkajan, seuraavien retkikuntien johtajan. Jatkajaa hän toivoi jo vuonna 1897.62 Vuoden 1899 retken jälkeen Nervander keskittyi omiin tutkimuksiinsa, matkoihinsa ja kirjoittamiseen.

\section{Kahdeksas retki 1902}

Tutkimusretkien suunnittelu siirtyi Meinanderille. Vuodelle 1901 aiottu kahdeksas Turun ja Rauman välisiin kirkkoihin suunnattu retki peruuntui, koska arkkitehti Lindgren sairastui. ${ }^{63}$ Retki toteutettiin seuraavana vuonna. Siihen osallistuivat johtajana ja tutkijana Meinander, arkkitehti Lindgren, Yleisten rakennusten ylihallituksen tehtävään osoittama arkkitehti Jarl Eklund ja polyteknikko Frankenhaeuser. ${ }^{64}$ Retkikunta koostui edellisen tapaan asiantuntijoista ja oli siksi varsin erilainen kuin ensimmäisten retkien taiteilijoista-, opiskelijoista- ja harrastelijoista muodostuneet ryhmät.

Neljä viikkoa kestäneen retken aikana käytiin seuraavissa kohteissa: Sauvon, Karunan, Raision, Naantalin, Maskun, Nousi- aisten, Mynämäen, Vehmaan, Askaisten, Kalannin, Pyhämaan, Pyhärannan ja Rauman kirkoissa sekä Louhisaaren ja Kankaisten kartanoissa. ${ }^{65}$ Kaikki kohteet oli tutkittu - tai niissä oli ainakin käyty - jo vuosien 1871 ja 1874 retkien aikana. Nyt kiinnitettiin erityistä huomiota arkkitehtuuriin ja valokuvaamiseen. Yhdistys esitti suorasukaisen toiveen vanhan kotimaisen arkkitehtuurin hyödyntämisestä uudessa tuotannossa:

Täten tulee kivikirkkojemme arkkitehtuuri ja niiden struktiivinen järjestelmä, mihin tähän asti ei juuri ole huomiota kiinnitetty, saamaan epäilemättä uutta valaistusta, ja täten asetetaan nuoria arkkitehtejämme vastakkain vanhan, yksilöllisen ja kotimaisen rakennustaiteen kanssa, mistä tietysti on koituva hyötyä nykyaikuiselle arkkitehtillisille virtauksille. ${ }^{66}$

Retkellä tehtiin 71 akvarellia ja piirustusta ja otettiin 181 valokuvaa. Retken työskentelystä on vaikea saada kokonaiskäsitystä, sillä retkikertomusta ei ilmeisesti laadittu, eikä retkestä julkaistu matkakirjeitä tai muuta kuvausta. Ainoat jäljet retkestä ovat maininnat pöytäkirjoissa, vuosikertomuksessa ja Museoviraston valokuvaluettelossa sekä 
eri puolille kuva-arkistoa hajonneissa piirustuksissa ja akvarelleissa. ${ }^{67}$ Hämmästyttävää on, että retkikuntien työn oma dokumentointi loppui näin tylysti juuri silloin, kun siihen osallistui hyvin asiantunteva, kokenut ja muinaismuistosuojeluun tiukasti sitoutunut joukko. Toisaalta viimeisestä retkestä on olemassa kattava tositeaineisto, sillä nyt jokainen osanottajien saama korvaus ja tarvikkeiden lasku todennettiin pöytäkirjan liitteenä. ${ }^{6}$

\section{Miksi retket loppuivat?}

Yhdistys oli tyytyväinen kahdeksannen retken tuloksiin eikä retkiä ollut tarkoitus lopettaa. ${ }^{69}$ Meinander, Lindgren ja Frankenhaeuser perustelivat yhdeksännen retken suuntaamista Ahvenanmaalle samoilla syillä kuin edellistä, alueen kirkoista tarvittiin valokuvia ja tarkempia arkkitehtonisia tutkimuksia. Yhdistys anoi 2800 markkaa valtionapua sekä Yleisten Rakennusten Ylihallituksen ylimääräiselle arkkitehdille lupaa osallistua matkaan, mutta Senaatti hylkäsi molemmat anomukset. ${ }^{70}$ Meinander ja Frankenhaeuser kuitenkin toteuttivat suunnitellun retken Muinaistieteellisen Toimikunnan edustajina. ${ }^{71}$ Tämän jälkeen ei yhdistys enää suunnitellut uusia taidehistoriallisia tutkimusretkiä.
Ratkaiseva syy raha-anomusten hylkäämiseen oli loppusyksystä 1902 Muinaismuistoyhdistyksessä paljastunut ns. Hahlin vaillinki. Rahastonhoitaja A. G. Hahl oli kavaltanut rahaa 1880-luvun lopulta lähtien ja noin puolet yhdistyksen omaisuudesta arvioitiin puuttuvan. ${ }^{72}$ Samaan aikaan yhdeksännen taidehistoriallisen retken kanssa Senaatin Kirkollisasiain Toimituskunta hylkäsi myös yhdistyksen paikannimihakemiston aineistokeruuta varten tekemän hakemuksen. ${ }^{73}$ Oli ymmärrettävää ettei yhdistyksen toimintaa haluttu tukea ennen kuin sen raha-asiat oli selvitetty eikä rahoitusta todennäköisesti voitu tässä tilanteessa hakea muualtakaan.

Taidehistorialliset tutkimusretket olivat taloudellisesti raskaita järjestää. Ne veivät suuren osan yhdistyksen vuosibudjetista ja ilman ulkopuolista rahoitusta niistä oli luovuttava. Jo aikaisemmin oli esitetty ajatus, että inventointiretkien järjestäminen kuului oikeastaan Muinaistieteellisen Toimikunnan tehtävänalaan. ${ }^{74}$ Suurien retkikuntien järjestämisestä saatettiin luopua ainakin salaa helpotuksesta huokaisten.

Monimiehinen ja pitkäkestoinen tutkimusretki alkoi ilmeisesti vaikuttaa myös metodina vanhentuneelta. Liikkuminen oli höyrylaivojen ja erityisesti rautatien myötä helpottunut ratkaisevasti ja yhdessä kohteessa pystyi vierailemaan aikaisempaan nähden niin nopeasti, ettei laaja paikasta toiseen etenevä kierros enää tuntunut tarpeelliselta. Myös perustava kuva-arkisto oli jo olemassa. Keväällä 1904 Meinander totesi, että suuret taidehistorialliset retket olivat "nykyisessä tilanteessa työvoiman hukkaamista", pari miestä pystyi hoitamaan sekä tietojen täydennykset että ennen tutkimattomien kohteiden tutkimisen. ${ }^{75}$ Taustalla oli optimistinen ajatus, ettei tärkeitä tutkimattomia kohteita enää ollut paljoakaan jäljellä ja väliin vielä jääneet yksittäiset ja vähemmän tärkeät kohteet olisivat nopeasti ja helposti tutkittavissa. Yhdistys oli siten saanut taidehistoriallisille tutkimusretkikunnille vuonna 1871 asettamansa tehtävän täytettyä.

Tavoitteen ja metodin muuttuminen pitkäkestoisista, monimiehisistä ja laajoja alueita tutkivista retkikunnista yhden tai kahden miehen käynteihin kuvastaa yleisempää ajattelutavan muutosta. Kokonaisuuksiin suuntautuneesta idealismista oli siirrytty nuoren polven asiantuntijoiden empirismiin, yksittäisten, tarkasti määrättyjen kohteiden 
ja kysymysten selvittämiseen. Vaeltava etsintä ja toisinaan sattumien ohjaama aineiston kerääminen ei ollut enää tiedettä vaan näyttäytyi pioneerisukupolven romanttisuutena. ${ }^{76}$

Herää myös kysymys oliko Emil Nervander ainoa henkilö, joka jaksoi vuosikymmenestä toiseen ponnistaa retken ideasta valmiiksi, suunnitella, ehdottaa, organisoida, johtaa ja hoitaa jälkityöt raportointeineen ja kuvaluetteloineen, vieläpä levittää tietoa retkistä suurelle yleisölle. Kun hän lopetti 59-vuotiaana retkien johtamisen, ne loppuivat pian täysin. Oli syy mikä tahansa korostaa retkien loppuminen vuoteen 1902 Nervanderin merkitystä retkien alullepanijana ja ylläpitäjänä.

\section{Mitä retkillä saatiin aikaan?}

Retkikunnan johtajan laatimat matkakertomukset ovat ilmaisultaan usein niukkoja eikä niissä kuvailla itse matkantekoa, olosuhteita tai dokumentointityötä. Tärkeä osa kertomusta oli tehtyjen kuvien luettelo. Kertomusten yhteenlaskettu sivumäärä on $3290 .{ }^{77} \mathrm{Li}$ säksi lähes kaikista tutkimusretkistä ilmestyi matkakirjeitä, jotka kuvaavat olosuhteita, välillä työskentelyäkin, maisemia ja dokumentoituja kohteita kontekstissaan. Matkakirjeet sijoittavat luettelomaiset raportit paikalleen konkreettiseen ympäristöön ja keruun todellisuuteen.

Retkien keskeinen ja työläin tavoite oli kuvadokumentointi. Kertomuksen saattoi koota ja kirjoittaa yksi henkilö kun saman retken kuvadokumentoinnista vastasi vähintään kolme piirtäjää. Kuvat olivat tärkeitä kaikkien asetettujen tavoitteiden kannalta, niitä tarvittiin suuren yleisön mielenkiinnon herättämiseen, uuden tuotannon inspiroimiseen ja ennen kaikkea tutkimukseen. Erityisesti ensimmäiset retket merkitsivät hyppäystä saatavilla olevien kuvien määrässä. ${ }^{78}$ Kotimaisen taiteen tutkijoilla oli 1870-luvun alussa käytössään vain vähän kuvia ja tutkimuksen piti tuottaa ne itse. Tilanne ei oleellisesti muuttunut 1900-luvun alkuun mennessä, vaikka yhdistyksen ja Muinaistieteellisen Toimikunnan dokumentointityö, kuvien kerääminen ja arkistointi kasvattivat kuvamäärää jatkuvasti. Kaikkiaan kahdeksan retkeä tuottivat 2726 kuvaa, joista noin 700 oli valokuvia.

Taidehistoriallisten retkikuntien työskentely keskittyi historialliseen aikaan, esihistoria rajattiin ulkopuolelle..$^{79}$ Aikarajauksen loppupää oli epämääräinen ja venyi 1800-luvulle asti. Keskiaikaiset kirkot painottuivat vahvasti kolmessa ensimmäisessä tutkimusretkessä. Kolmannella retkellä työskentelytapa muuttui tarkemmin inventoivaksi, ja kaikki, myös vähemmän tärkeäksi katsotut kohteet, dokumentoitiin ainakin alustavasti. Kirkkoarkkitehtuurin dokumentointi oli kolmannesta retkestä lähtien järjestelmällistä: jokaisesta kirkosta tehtiin vähintään pohjakaava ja eksteriööri, kiinnostavammista myös interiöörikuva.

Suurin tutkimusretkikauden aikana tapahtunut dokumentoinnin muutos oli kameran saaminen mukaan vuodesta 1892 lähtien. Valokuvaus oli hankalaa pitkillä tutkimusretkillä: välineistö painoi, kemikaalit olivat vaikeita kuljettaa, lasilevyt vaativat pimeätä tilaa ja kameroiden käyttö taitoa. Valokuvalla saatiin esille kohteen tarkka muoto, mutta tekniikalla oli ongelmansa. Pimeät kirkot, joita varsinkin keskiaikaiset olivat, rajoittivat kuvausmahdollisuuksia eikä valokuvalla voinut dokumentoida värejä. Toisaalta juuri liikkumattomat arkkitehtuuri-, esine- ja maalauskohteet sopivat pitkää valotusaikaa vaatineen tekniikan kohteeksi.

Erilaiset piirtämisen, maalaamisen ja niitä yhdistävät menetelmät olivat keskeisessä 


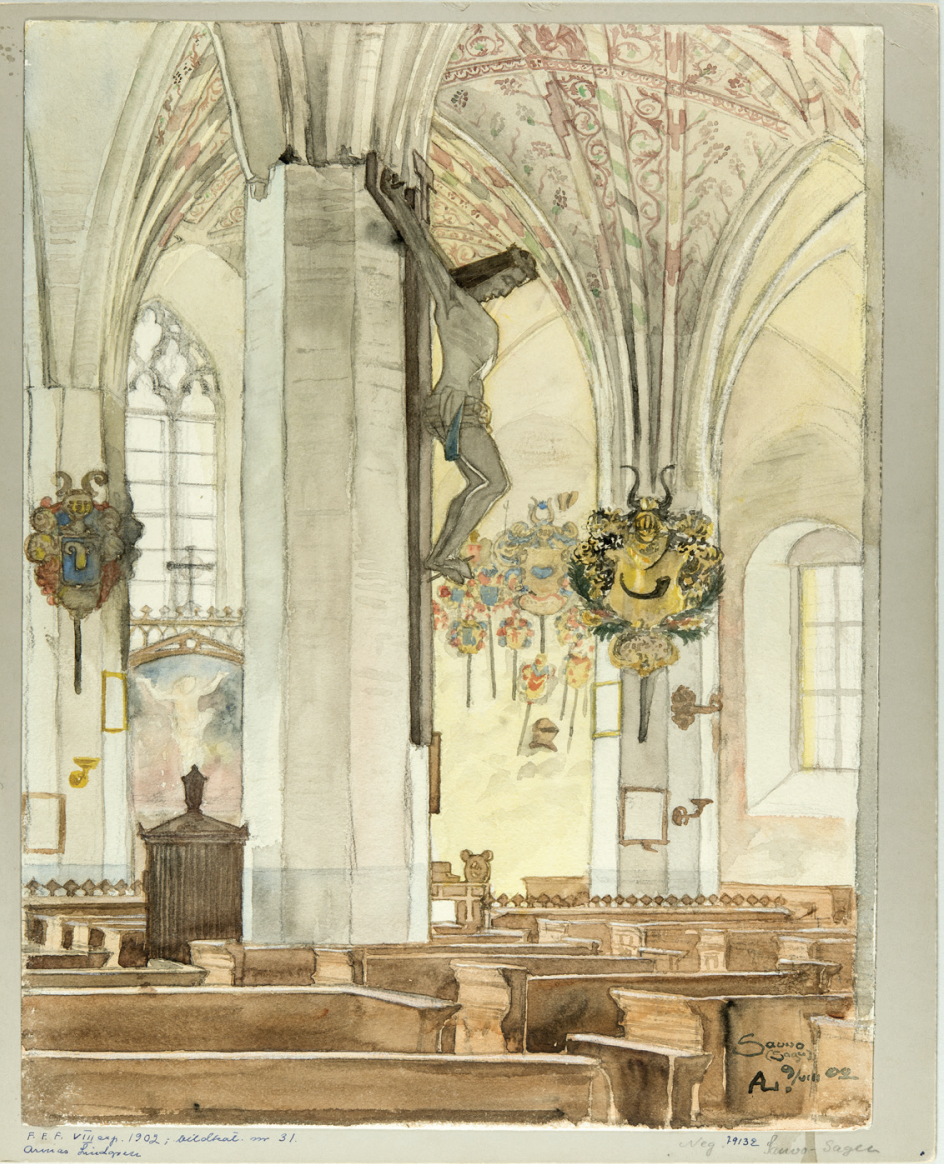

Kuva 5. Armas Lindgren, Sauvon kirkon interiööri, 9.8.1902. Akvarelli, $30 \times 45 \mathrm{~cm}$. Taidehistoriallinen retkikunta vieraili Sauvossa ensimmäisen kerran vuonna 1871. Kirkon arkkitehtuurista tehtiin tällöin kolme detaljikuvaa, kaksi portaaleista ja yksi kuori-ikkunasta. Lindgrenin akvarelli edustaa toisenlaista dokumentointitapaa, jossa kuvauksen kohteena on interiöörin rakenne, kokonaisuuden eri ikäiset osat, niiden sijainti ja valo. Museoviraston kuvakokoelmat, Historian kuvakokoelma, Helsinki. asemassa viimeiseen retkeen saakka. Eniten tehtiin lyijykynäpiirustuksia, laveerattuja lyijykynäpiirustuksia ja akvarelleja. Vaikuttaa siltä, että tekniikoita sekä sovellettiin kohteiden mukaan että kokeiltiin matkan aikana, tehtiin esimerkiksi kalkeerauksia eli maalausten jäljentämistä ohuen paperin läpi piirtäen, hierrekuvia, kollaasheja, piirustuksia tummalle paperille ja eräänlaisia laveerattuja ääriviivapiirustuksia. Tekstiilien tekstuurin, kuvioinnin ja värityksen toistamista kokeiltiin monin tavoin. Eri tekniikoilla pyrittiin saamaan esille eri asioita, varsinkin vuosien 1896 ja 1899 retkillä samoja seinämaalauksia dokumentoitiin kolmella eri tekniikalla eli akvarellilla, valokuvauksella ja kalkeerauk$\sin$.

Valmistetut kuvat olivat usein pienikokoisia. Poikkeuksen tekivät suuret keskiaikaisten seinämaalausten ja esimerkiksi Saloisten kirkon alttarikaapin maalausten kalkeeraukset. Monet keskiaikaisten veistosten kuvat tehtiin keskimäärin vain noin $11 \mathrm{x}$ $20 \mathrm{~cm}$ kokoiselle paperille. Syy pieneen kokoon oli käytännöllinen, paperit piti kuljettaa mukana ja saada säilymään suorina koko matkan ajan. Näyttää siltä, että kuvien koko hieman kasvoi vuosien myötä.
Kameran tulo mukaan näkyi muun kuvadokumentoinnin muutoksena. Varsinkin viimeisellä retkellä, kun suuri osa kuvista oli jo valokuvia, keskityttiin piirroksissa ja akvarelleissa aikaisempaa enemmän vaikutelmaan, tunnelmaan, valaistukseen ja väritykseen. Valokuvaus antoi mahdollisuuden jättää tiukka viivapiirustus vähemmälle. Parhaimmin muutosta voi tarkastella kahden ensimmäisen ja viimeisen retken välillä, koska niillä dokumentoitiin samoja kohteita.

Kohteesta tehdyn dokumentoinnin lisäksi retkillä valmistetut kuvat ja paperit sisältävät monenlaista metatietoa. Paperiin, toisinaan kuva-alan päälle, on merkitty kokoelman omistaja ja kohteen tunnistustieto suomeksi ja ruotsiksi, retken järjestysnumero ja kuvan järjestysnumero. Tekijän signeeraus ja päivämäärä puuttuu monista ensimmäisen ja toisen retken kuvista. Kolmannesta retkestä lähtien kuvien tekijät on yleensä mainittu kertomuksen kuvaluettelossa. Kuvissa on toisinaan paljon kirjoitettua tietoa kohteesta kuten tarkennuksia aiheista ja värien kuvailua sanoin. Metatietoa on myös kuvauskohteiden valinta. Se tehtiin kiireen vuoksi nopeasti, vain kiinnostava kuvattiin ja samalla suljettiin jotakin muuta pois.

Kuvakokoelmaa tarkastellessa ei voi kuin hämmästyä dokumentoitujen kohteiden mo- 
ninaisuutta. Taidehistoriallisiin tutkimusretkiin liitetty käsitys keskiaikaisten kohteiden tutkimiseen keskittyneenä hankkeena sulaa pois mitä enemmän kuvia näkee. Kolme ensimmäistä retkeä painottuivat keskiaikaan, mutta jo neljäs, vuoden 1887 retki, dokumentoi huomattavasti enemmän muuta. Tähän vaikutti tietysti se, että vähitellen siirryttiin pois keskiaikaisia kirkkoja eniten sisältäviltä alueilta, mutta 1880-luvulla esille nousi aikaisempaa selvemmin myös retkikuntien kiinnostuksen laaja-alaisuus, huomion suuntaaminen käyttöesineisiin ja taideteollisuuskohteisiin. Tämä jo ensimmäisen retkikunnan ohjelmaan sisältynyt alue on mielestäni jäänyt aiemmin täysin huomiotta tutkimusretkistä puhuttaessa. Dokumentoinneista voi seurata, miten retkikunta tarkensi katseensa esimerkiksi kynttilänjalkoihin, tuoleihin, oviin, koristemaalauksiin, erilaisilla tekniikoilla toteutettuihin ornamentteihin ja hautoihin.

\section{Miksi retkien tuloksia ei tunneta?}

Suhtautuminen taidehistoriallisiin tutkimusretkiin on ollut epämääräisen ohittavaa, eikä niillä tehtyä työtä ole pidetty aivan vakavasti otettavana tutkimuksena. Käsitys on voinut lähteä liikkeelle jo tutkijoista itsestään, sillä
Muinaismuistoyhdistyksen perustajat Nervander ja Johan Reinhold Aspelin (18421915) esittivät itse olevansa "vain" kerääjiä, aineiston kokoajia. Viimeistään 1920-luvulla heidät nähtiin oppiaineen esivaiheen, ns. romanttisen ensimmäisen sukupolven edustajina, tulevien oikeiden koulutettujen tutkijoiden tien pohjustajina. ${ }^{80}$ Mielestäni tämä vähättelevä näkemys on, ehkä huomaamattakin, jäänyt elämään ja sävyttänyt käsitystä varhaisen suomalaisen tutkimuksen tasosta - ikään kuin oppiaineiden alku missään alkaisi muualta kuin alusta. Ääneen lausumaton käsitys tutkimuksen myöhäisestä alkamisesta ja jonkinlaisesta noloudesta on estänyt analyyttisen tarkastelun ja kiinnostumisen siitä mitä taidehistoriallisilla tutkimusretkillä todella tehtiin.

Ajatus Suomen takapajuisuudesta voi olla peräisin myös yleisemmin muinaismuistosuojelusta itsestään. Päättäjiin pyrittiin vaikuttamaan argumenteilla, joiden mukaan Suomi oli pahasti jäljessä muista sivistysvaltioista. ${ }^{81}$ Varsinkin tanskalaista muinaistutkimusta pidettiin esikuvallisesti järjestettynä ja kansainvälisesti korkeatasoisena. Siellä muinaismuistojen dokumentointi ja tietojen kokoaminen järjestettiin jo 1800-luvun en- simmäisellä vuosikymmenellä. Systemaattisesti maata läpikäyvät tutkimusretket, ns. kahden miehen herredsrejserne, aloitettiin vuonna $1873{ }^{82}$ Ruotsissa tutkimusretket ja tulosten julkaisu alkoivat 1840-luvulla, kun kruunu rahoitti Mandelgrenin dokumentointiretkiä ja sarjaa Monuments scandinaves du moyen âge $(1847,1855-1862){ }^{83}$ Suomen Muinaismuistoyhdistystä vastaava Svenska Fornminnesföreningen perustettiin vuonna 1869. ${ }^{84}$

Siihen nähden, että Suomi oli irrotettu yhteydestään Ruotsiin ja sen muinaismuistohallinnon kehitykseen, ei yhdistyksen perustaminen vuonna 1870 ja sen nopeasti aikaansaama ensimmäinen taidehistoriallinen tutkimusretki vaikuta dramaattisen myöhäiseltä. ${ }^{85}$ Yhdistys myös pystyi niukoista resursseistaan huolimatta inmeteltävän pitkään ja sitkeästi järjestämään suuritöisiä ja paljon varoja nieleviä retkiä sekä pitämään kiinni kerran laatimastaan ohjelmasta, jonka tavoitteena oli kattaa koko maa.

Tärkein syy epämääräiseen mielikuvaan retkikuntien työn sekavuudesta on mielestäni kuva-aineiston vaikeassa hahmotettavuudessa ja siinä, ettei retkiä ja niiden tuottamaa aineistoa esittelevää kokonaisjulkaisua tehty. Dokumenttikuvien julkaisemisen tärkeys 
kyllä ymmärrettiin yhdistyksessä heti, ne tuli saada suuren yleisön ja kansainvälisen tiedeyhteisön ulottuville. Ideaalitilanteessa edustava otos retkillä tehdyistä kuvista olisi ollut helposti ja pysyvästi yleisön nähtävillä, mutta pysyvää näyttelyä ei saatu aikaan. ${ }^{86} \mathrm{Jo}$ toisen retken jälkeen kuvia oli niin paljon, että niiden säilyttäminen ja tarkastelu oli Historiallisen museon ahtaissa tiloissa vaikeaa.

Retkien tuloksia Helsingissä esitteleviä näyttelyitä järjestettiin neljä, vuosina 1871 , 1874,1894 ja $1897 .{ }^{87}$ Kuvia oli esillä myös kolmessa muussa yhteydessä. Nervander toimi vuonna 1881 Helsingissä järjestetyn Ensimmäisen suomalaisen taideteollisuusnäyttelyn komissaarina. ${ }^{88}$ Näyttely alkoi historiallisella osuudella, joka sijoitti suomalaisen keskiaikaisen kirkollisen esineistön taideteolliseen kontekstiin. Esillä oli myös taidehistoriallisilla retkillä tehtyjä kuvia. ${ }^{89}$ Yhdistyksen Pariisin 1900 maailmannäyttelyn osastosta muodostui Nervanderin työn kunnianosoitus. Pitkien pohdintojen jälkeen päädyttiin osaston linja rajata tiukasti keskiaikaan. ${ }^{90}$ Vuosikertomuksen mukaan: "[...] taiteellisesti sivistyneen ulkomaisen yleisön huomio helpoimmin kiinnitetään Suomessa menneinä aikoina ilmautuneihin eurooppalaisiin taideheijastuk- siin, jos näytteille asetetaan valiokeräelmä katoolisen ajan kirkollistaiteellisia muistoja”, toisin sanoen retkien tuottamia kuvia niistä. ${ }^{91}$ Ateneumissa keväällä 1903 järjestetystä Taidehistoriallisesta näyttelystä tuli tutkimusretkikauden testamentti. Esillä oli nyt kuvien sijasta aitoja keskiaikaisia esineitä ja lisäksi kuvia 1700-luvun Pohjanmaan kirkkojen seinämaalauksista. Kolme viikkoa auki olleeseen näyttelyyn oltiin hyvin tyytyväisiä, se oli aatteellinen voitto. ${ }^{22}$

Ensimmäisen ehdotuksen painetusta kuvajulkaisusta teki yhdistyksen puheenjohtaja Zachris Topelius jo vuonna 1874, mutta sitä ei voitu toteuttaa samana vuonna kuin kallis retkikunta pantiin toimeen. ${ }^{93}$ Retkien järjestämisestä ja kuvien julkaisemisesta näyttää jatkossakin muodostuneen toisensa poissulkevat hankkeet. 1900-luvun alussa kuvajulkaisun otti asiakseen erityisesti Meinander. Taidehistoriaan ja keskiaikaan perehtyneenä hän ymmärsi kuvajulkaisujen ja niiden kautta leviävän ja saatavan kansainvälisen tiedon keskeisen merkityksen tutkimukselle. Hänen vuonna 1904 yhdistyksen johtokunnalle tekemänsä esitys aineiston julkaisemisesta ja valtionavun anomisesta sai aikaan, ehkä esittäjän yllätykseksi, vilkkaan ja osin tuohtu- neen reaktion. Lopputuloksena oli, että hanketta lykättiin "toistaiseksi". ${ }^{94}$

Viime kädessä julkaisuasiassa törmättiin kerta toisensa jälkeen rahoituksen ongelmiin, varsinkin kuvien painamisen kalleuteen. Toiseksi juututtiin hankkeen ja retkillä tuotetun aineiston suuruuteen. Yli kahteentuhanteen kuvaan, satoihin valokuviin ja loputtomiin käsinkirjoitettuihin raporttisivuihin paisunut aineisto aiheutti ylipääsemättömiä ja osin periaatteellisia näkemyseroja: miten se pitäisi julkaisua varten järjestää, mitä valita, mitä jättää pois. Miten suhtautua ensimmäisten retkien hapuileviin tulkintoihin, miten aineiston heterogeenisyyteen? Kuka toimitustyön tekisi ja oliko aineistoa edes mahdollista järjestää uusia tieteellisiä vaatimuksia tyydyttäväksi kokonaisuudeksi? Se että julkaisua ei saatu aikaan, on mielestäni tärkein tekijä käsitykseen yhdistyksen taidehistoriallisilla retkillä tehdyn aineiston "mahdottomuudesta", sattumanvaraisuudesta tai amatöörimäisyydestä. Kokonaisjulkaisu ei kaatunut aineiston laatuun vaan määrään.

Toinen tärkeä syy aineiston tuntemattomuuteen on se, että retkillä tehdyt kuvakokonaisuudet hajotettiin ilmeisesti jo varhaisessa vaiheessa, ehkä jo heti retkien jälkeen, eri 
puolille kuva-arkistoa. ${ }^{95}$ Kuvat jaoteltiin kohteen sijaintipaikkakunnan, tekniikan ja iän mukaan. Arkkitehtuuri, maalaustaide, veistetyt kuvat, saarnatuolit, tekstiilit, kirkolliset ja profaanit esineet, kartanot ja kansanrakennukset sijoitettiin erilleen toisistaan. Myös piirustuspaperien ja pohjapahvien koko vaikutti jaotteluun. Lopputuloksena on, että esimerkiksi yhdessä kirkossa tehdyt kuvat voivat sijaita fyysisesti kymmenessä, kaikkien retkien kuvat ehkä sadoissa eri arkistolaatikoissa. Kokonaisen retken kuvien saaminen esille kokonaisuutena on käytännössä lähes tai täysin mahdotonta.

Kuvia ei siis arkistoitu kontekstin mukaan, jolloin esimerkiksi yhden kirkon esineistöstä tehdyt dokumentit olisivat pysyneet yhdessä. Toimintatapa paljastaa silloisen tutkimuksen lähestymistavan, jossa kirkkoa ei nähty eri-ikäisten kohteiden muodostamana toiminnallisena kokonaisuutena vaan yksittäisiä esineitä, maalauksia ja arkkitehtuuria tarkasteltiin ryhminä ja niiden sisäisinä typologioina. Myöskään kunkin retken työstämää aineistoa ei pidetty kokonaisuutena, jonka osien jäljitettävyys olisi ollut tärkeää.
Viimeksi koko kuva-aineiston näki vuosina 1968 ja 1969 tutkija Marta Hirn. Hän kävi läpi taidehistoriallisten retkikuntien kuvat ja merkitsi kuva-arkiston Historiallisen osaston Kuvaluettelossa oleviin retkikuntien kuvaluetteIoihin jokaisen kuvan kohdalle vuosiluvun ja merkinnän "på plats". Hirn ei lisännyt luetteloon kuvan signumia, siis tietoa siitä, missä kuva fyysisesti sijaitsi ja näin mahdollisuus kattavan paikkatietoluettelon aikaansaamiseen menetettiin siltä kerralta. ${ }^{96}$

Menossa oleva digitointi helpottaa vähitellen kuvien näkemistä, mutta ei vielä varsinaisesti niiden löytymistä, sillä kaikkia retkikuntia tai edes yksittäisen retken kuvat yhteen liittävää hakusanaa ei ole olemassa. ${ }^{97} \mathrm{His}$ toriallisen osaston Kuvaluettelo 1842-1909 -nidokseen, nyttemmin sen monistettuun kopioon, lisätään merkintä digitoidun kuvan numerosta tai kirjain $\mathrm{M}$ sitä mukaa kuin digitointi etenee ja kuva liitetään Musketti-tietokantaan. Vanha ja kunnianarvoisa nidos toimi näihin päiviin asti tarpeellisena apuvälineenä retkikuntien kuvia jäljitettäessä, samalla kun siitä itsestään muodostui aikojen kuluessa tärkeä ja sen kopiosta edelleen karttuva arkistohistorian lähde. Tutkimukseni tuo esille Museoviraston kuva- ja asiakirjakokoelmien säilyttämän aineiston suuren arvon sekä niiden sisältämän informaation että arkistohistorian kannalta. Toisinaan yksittäisen kuvan sijainti arkistossa herättää yhtä paljon kiinnostavia kysymyksiä kuin itse kuvan sisältö.

Suomen Muinaismuistoyhdistyksen taidehistorialliset retket ovat merkittävä osa Suomen kulttuurihistoriaa. Ne tuottivat perustutkimusta ja dokumenttiaineistoa, lisäsivät tietoa ja herättivät osaltaan kiinnostusta kotimaan menneisyyttä kohtaan sekä yleisesti että paikallisesti jokaisella käymällään kahdella sadalla paikkakunnalla. Retket ovat myös monipuolisen kiehtova ilmiö ja ne sijoittuivat ajanjaksoon, jolloin moni asia muuttui. Kun ensimmäinen retkikunta vaelsi katastrofaalisesta nälänhädästä juuri toipuvassa agraarisessa suuriruhtinaskunnassa, kulki viimeinen teollistuvassa maassa käyttäen hyväkseen liikenteen, tiedonkulun, tekniikan ja tutkimuksen sille suomia uusia mahdollisuuksia ja itseensä luottaen. 


\section{Viitteet}

1 "Suomen Muinaismuistoyhdistys", Luettu 19.5.2017, http://wwww.muinaismuistoyhdistys. fil/.

2 Marta Hirn julkaisi vuonna 1970 ansiokkaan, mutta suppean esityksen retkien järjestelyistä ja tuloksista. Marta Hirn (toim.), Kuvia katoavasta Suomesta:

Suomen Muinaismuistoyhdistyksen taidehistoriallisten retkikuntien piirroksia ja akvarelleja vuosilta 1871 1902 (Helsinki: Weilin+Göös, 1970). Hyvä kuvaus Yhdistyksen toiminnasta retkien suhteen ks. A.

M. Tallgren, Suomen Muinaismuistoyhdistyksen 50-vuotiskertomus, SMYA XXX (Helsinki: SMY, 1920), 72-82. Sixten Ringbom, Art history in Finland before 1920: The history of learning and science in Finland 1828-1918, 15b. (Helsinki, Societas Scientiarum Fennica, 1986), 33-34.

3 Artikkeli kuuluu Koneen Säätiön rahoittamaan tutkimusprojektiini Luovaa voimaa etsimässä,

Taidehistorialliset tutkimusretket uuden suomalaisen arkkitehtuurin, taiteen ja taideteollisuuden edistäjinä 1871-1902.

4 Emil Nervander piti tehokkaimpana neljän hengen ryhmää, jossa kolme keskittyi piirtämiseen ja yksi kuvailuun ja tulkintaan. Museovirasto (MV) Suomen Muinaismuistoyhdistyksen arkisto (SMYa) pöytäkirja (pk) 7.5.1885 § 6. Expeditions förslag Till Finska Fornminnesföreningen, 18.4.1896, MV SMYa Emil
Nervanderin arkisto (ENa) Ht28.

5 Suomen Muinaismuistoyhdistyksen pöytäkirjat I 1870-1875, (Helsinki, SMY, 1909), SMY pk 20.2.1871 §2, 46. SMY pk 6.3.1871 §3, 51-52. Pöytäkirjaviitteet ohjaavat jatkossa tähän vuosien 1870-1875 pöytäkirjat sisältävään julkaisuun ja vuosien 18761885 osalta osaan II (1915). Vuoden 1886 ja sitä myöhemmät pöytäkirjaviitteet viittaavat suoraan kyseisiin asiakirjoihin.

6 Mandelgrenin pyytäminen oli tohtori K. F. Ignatiuksen idea. SMY pk 20.2.1871 §2, 48. SMY pk 6.3.1871 §3, 53. Ignatius viittasi Mandelgrenin toimintaan Kööpenhaminan "Oldnordiska sällskapetissa". Nimityksessä menivät sekaisin Oldskriftselskabet ja Oldnordiske Museum. 7 Leena Valkeapää, "Tutkimusmatkalla Suomessa 1871", teoksessa Emil Nervander, Kesämatkoja Suomessa: Ahvenanmaalla ja Turun seudulla, käännös Markus Hiekkanen, johdanto Leena Valkeapää (Helsinki: SKS, 2010), 24-26. Nervanderin teos ilmestyi alun perin 1872

8 Valkeapää, "Tutkimusmatkalla Suomessa 1871", 9-12.

9 Ahlbergista on retkikunnan lähteissä hyvin vähän tietoa. Kyseessä oli todennäköisesti Teuvalla syntynyt Karl Mathias Emil. "Ylioppilasmatrikkeli", Luettu 15.11.2016, http://www.helsinnki.fi/. ylioppilasmatrikkeli/1853-1899/henkilo php?id=18724.
10 Kirjeet julkaistiin kirjana: Emil Nervander,

Sommarresor i Finland: På Åland och Åbo-trakten (1872). Käännös ilmestyi vuonna 2010 ks. viite 7. 11 Nervander, Kesämatkoja Suomessa, Kumlinge 158-163, Taivassalo 206-214.

12 Nervander, Kesämatkoja Suomessa, 218-222. 13 SMY pk 27.1.1874 §4, 238; SMY pk 6.3.1874 §2, 242-244.

14 SMY pk 4.5.1874 §2, 250-252; 19.5.1874 §2, 264. 15 SMY pk 6.3.1874 §2, 242-244. 16 SMY pk 4.5.1874 §2, 250-252.

17 G. M-r. [G. Melander], "Karl Fredrik Slotte", teoksessa Kansallinen elämäkerrasto $V$, (Porvoo: WSOY, 1934), 146; Maria Vainio-Kurtakko, Idylle eller verklihhet? Albert Edelfelt och Gunnar Berndtson i det moderna genombrottets ambivalens, FFFT 117, (Helsingfors: FFF, 2010), 40-41;

“Ylioppilasmatrikkeli”, Luettu 17.8.2016, http://www. hels sinki.fi/ylioppilasmatrikkeli/1853-1899/henkilo php?id=18747. (Nordström).

18 Retkikunta kävi Köyliönkartanossa, jonka tuolloin omisti Emil Waldemarin isoveli Axel Fredrik Nicolaus. Tor Carpelan, Finsk biografisk handbok (Helsingfors: Edlunds förlag, 1903), 350-351.

19 Kalannin alttarikaapin tutkimuksen varhaishistoriasta ks. Elina Räsänen \& Leena Valkeapää, "Sukupuolten tulkintoja ja 'venäläisiä tyyppejä' - Kalannin alttarikaapin varhaisesta 
tutkimushistoriasta", Suomen Museo 2013, 2014 :

5-31. Alttarikaappiin liittyvistä kansanuskomuksista ja niiden liittymisestä tutkimushistoriaan ks. Leena Valkeapää, "Tietämisen tavat, Uskomustarinat ja tutkimus Kalannin alttarikaapin äärellä", Tahiti 3/2016, http://tahiti.fi/03-2016/tieteelliset-artikkelit// tietamisen-tavat-uskomustarinat-ja-tutkimus-kalanninalttarikaapin-aarella/

20 Matkakirjeiden kirjoittajien henkilöllisyyden pohdintaa ks. Räsänen \& Valkeapää, "Sukupuolten tulkintoja ja 'venäläisiä tyyppejä'”, 8 .

21 Näyttelyluettelo Finska Fornminnesföreningens EXPOSITION 1874 julkaistiin myös pöytäkirjojen liitteenä. Ks. Suomen Muinaismuistoyhdistyksen pöytäkirjat I, 277-282. Museoviraston Historiallisen osaston kuvaluettelo 1842-1909 sisältää II retken kuvaluettelon, jonka alussa todetaan sen olevan "pääpiirteissään sama" kuin näyttelyn luettelo. 22 SMY pk 20.9.1875 §1, 345.

23 A. M. Tallgren, Suomen Muinaismuistoyhdistyksen 50-vuotiskertomus, SMYA XXX, (Helsinki: SMY, 1920), 145-146.

24 Leena Valkeapää, Vapaa kuin lintu: Emil Nervanderin elämä (Helsinki: Taidehistorian seura, 2015), 76, 89-91.

25 SMY pk 17.2.1882 §5, 275. SMY pk 2.5.1882 §6, 286. Timo Salmisen arviossaan esittämä kommentti osui oikeaan. Tauko retkien järjestämisessä johtui lähinnä rahapulasta, ei Yhdistyksen toisaalle kääntyneestä huomiosta. Ks. Valkeapää, Vapaa kuin lintu, viite 558 ja Timo Salminen, "Antikvaari ja esteetikko", Tieteessä tapahtuu 1/2016: 67. 26 Tallgren, Suomen Muinaismuistoyhdistyksen 50-vuotiskertomus, 147, 149.

27 Tallgren, Suomen Muinaismuistoyhdistyksen 50-vuotiskertomus, 76.

28 Tallgren, Suomen Muinaismuistoyhdistyksen 50-vuotiskertomus, 76.

29 SMY pk 7.5.1885 §6, 408-410.

30 Valkeapää, Vapaa kuin lintu, 100-102.

31 Tiedot Aspista ks. Kuka kukin oli, Luettu 31.8.2016, https://fi wikisource.org/wiki/Kuka kukin oli: A\#as. Hertta Tirranen, "Agathon Reinholm", teoksessa Kalevalaseuran vuosikirja 40 (Porvoo, Helsinki: WSOY, 1960), 68-81. Ildikó Lehtinen, "Agathon Reinholm - suomalainen taiteilija sukukansojen parissa", Suomen Museo 2004, 2005. Tuula Rantanen, "Vuori, Kaarlo (1863-1914)", teoksessa Suomen kansallisbiografia 10 (Helsinki: SKS, 2007), 728-729.

32 SMY/THRK 1885, mf rulla 2.

33 Nervanderin kirjeet ilmestyivät

Hufvudstadsbladetissa (Hbl) 2.7.-24.10. 27 osassa, I-X on otsikoitu "Sommarresor i Finland. Bref från en konsthistorisk expedition”, XI-XII ovat nimellä Från en konst-historisk expedition i Finland. Olen aikaisemmin virheellisesti ilmoittanut Uuden Suomettaren kirjeet Nervanderin kirjoittamiksi. Ks. Valkeapää, Vapaa kuin lintu, 242. Uuden Suomettaren kuusi kirjettä ilmestyivät 21.8.-24.9. otsikolla "Muinaismuistoyhdistyksen taidehistoriallisen tutkijakunnan matkat" kesällä 1885.

34 "Muinaismuistoyhdistyksen taidehistoriallisen tutkijakunnan matkat kesällä 1885", Uusi Suometar 11.9.1885 no 210.

35 MV SMY pk 23.2.1887 §11, 29.2.1887 §5.

36 Nervander teki keväällä 1886 senaatin rahoittaman opintomatkan Ruotsiin, Tanskaan ja Lyypekkiin. Heti palattuaan hän osallistui Hattulan ja Lohjan kirkkojen seinämaalausten tutkimiseen ja restaurointiin ja ryhtyi kirjoittamaan ensimmäistä Suomen keskiajan taiteen yleisesitystä "Kirkollisesta taiteesta Suomessa keski-aikana / Den kyrkliga konsten i Finland under medeltiden". Valkeapää, Vapaa kuin lintu, 102-103. 37 Grahn ks. Matrikkeli sisältävä elämäkerrallisia tietoja Teknillisen reaalikoulun, Helsingin polyteknillisen koulun ja Suomen polyteknillisen opiston opettajista ja oppilaista 1848-1897 sekä historiikit oppilaitoksen, Teknoloogisen yhdistyksen ja Polyteknikkojen yhdistyksen toiminnasta,

(Kotka: Polyteknikkojen yhdistys, 1899), 301. Asko Salokorpi, Selim A. Lindqvist Arkkitehti (Helsinki: Sarmala Oy, Rakennusalan Kustantajat RAK, 2001). Ks. myös "Arkkitehtuurimuseo: Selim A. 
Lindqvist", Luettu 16.8.2016, http://www. mfa fi/ arkkitehtiesittely?apid=3837.

38 MV SMY pk 31.1.1888 §2.

39 MV SMY pk 14.4.1891 §7, 21.5.1891 §6.

40 Stolpe ks. "Matrikkeli sisältävä elämäkerrallisia tietoja", 313. "Arkkitehtuurimuseo: Lars

Sonck", Luettu 16.8.2016, http://www.mfa.fil

arkkitehtiesittely?apid=3875.

41 MV SMY pk 7.5.1892 §3.

42 Emil Nervander, "Sommarresor i Finland. Bref från årets konsthistoriska expedition", Hbl 2.7.1892 no 176, 19.10.1892 no 285. Mikko Härö, Suomen muinaismuistohallinto ja antikvaarinen tutkimus:

Muinaistieteellinen toimikunta 1884-1917 (Helsinki: Museovirasto, 1984), 121-123. A.M.T. [Aarne Michaël Tallgren], "Hackman, Alfred", teoksessa Kansallinen elämäkerrasto, II osa F-I (Porvoo: WSOY, 1929), 329-330.

43 Hirn mainitsi Eliel Aspelinin retken valokuvaajana, mutta häntä ei mainita lähteissä. Hirn, Kuvia katoavasta Suomesta, 90. Nervander luetteli osallistujat kahdessa lähteessä: SMY:n taidehistoriallisten retkikuntien kertomukset, Retki 1892, mf rulla 3 ja Emil Nervander, "Sommarresor i Finland. Bref från årets konsthistoriska expedition", $H$ bl 2.7.1892 no 176.

44 MV SMY pk 24.4.1888 §4. Konsepti V retken suunnitelmaksi, MV SMYa ENa Ht27, Nippu
Taidehistoriallinen retkikunta 1892. MV SMY pk 11.3.1892 §3.

45 Kirjeet ilmestyivät 2.7.1892-24.4.1893 ensin nimellä Sommarresan i Finland, Bref från årets konsthistoriska expedition ja vuodenvaihteen jälkeen nimellä Från trakterna af Björneborgska banan. 46 MV SMY pk 16.3.1894 §4.

47 Nervander, Expeditions förslag Till Finska Fornminnesföreningen, 18.4.1896, Ht28. E. N. [Nervander], "Kesämatkoja Suomessa. Pohjois Pohjanmaalla”, Päivälehti 22.7.1896 no 167 48 Lindgren ks."Arkkitehtuurimuseo: Armas Lindgren", Luettu 16.8.2016, http://www.mfa.fi/ arkkitehtiesittely?apid=3830. Wikström ks. "Matrikkel sisältävä elämäkerrallisia tietoja”, 365. Ritva Wäre,

"Sucksdorff, Victor (1866-1952) arkkitehti", teoksessa Suomen kansallisbiografia 9, (Helsinki: SKS, 2007), 399-400.

49 "Muinaismuistoyhdistyksen taidehistoriallinen retkikunta", Päivälehti 23.10.1896 no 247. Muut lähteet eivät mainitse Hackmania. Hän on varakkaana miehenä voinut hyvin osallistua osaan tai koko matkaan omalla kustannuksellaan.

50 Yrjö Blomstedt ja Sucksdorff tekivät vuonna 1894 SMY:n rahoittaman retken Suomen ja Vienan Karjalaan. Tallgren, Suomen Muinaismuistoyhdistyksen 50-vuotiskertomus, 120121. Retken Kainuun puoleisesta osasta tarkemmin ks. Helena Lonkila, Syvällä sydänmaassa: Yrjö Blomstedtin ja Victor Sucksdorffin Kainuu (Jyväskylä: University of Jyväskylä, 2016).

51 Nervander kuvasi työskentelytapaa seitsemännen retken suunnitelmassa. Nervander 15.2.1899, Förslag till en konsthistorisk expedition sommaren 1899. SMY johtokunnan pk 16.2.1899 liite A. MV SMYa. Tehdyt kuvamäärät ks. Päivälehti 23.10.1896 no 247.

52 E. N., "Kesämatkoja Suomessa, Pohjois

Pohjanmaalla", Päivälehti 22.7.1896 no 167 ja "Kesämatkoja Suomessa II", Päivälehti 22.8.1896 no 194.

53 Berättelse öfver Finska Fornminnesföreningens sjette konsthistoriska expedition sommaren 1896. Nykarleby-Tornio, afgifven af E. Nervander. Retkikertomus ss. 295-343, MV SMYa mf 3. Kalannin kaapin dokumentoinnista ks. Räsänen \& Valkeapää, "Sukupuolten tulkintoja ja 'venäläisiä tyyppejä'”, 9-15. 54 MV SMY Johtokunta pk 16.2.1899 Liite A. 55 Nervander, Päivälehti 22.7.1896 no 167. 56 MV SMY johtokunta pk 9.3.1897 §2. 57 MV SMY pk:t 9.3.1897 §2, 18.3.1897 §3, 7.5.1897 $\S 1$, pk 30.5.1897 §1, pk 3.5.1899 §4. Pöytäkirjan 3.5.1899 mukaan Ylihallitus ei myöntänyt arkkitehtia "kuten ennen on ollut tapana". Tavaksi koettu käytäntö ei ollut kovin vahva, sillä Ylihallituksen arkkitehti oli saatu mukaan retkille kolmasti, vuosina 1871, 1892 ja 1896. 
58 Meinander ks Mikko Härö, Suomen

muinaismuistohallinto 1884-1917 (Helsinki:

Museovirasto, 1984), 125-126; Eklund ks.

"Arkkitehtuurimuseo: Jarl Eklund", Luettu 16.8.2016, http://mfa fi/arkkitehtiesittely?apid=3135. Cederhwarf ks. "Ylioppilasmatrikkeli", Luettu 16.8.2016, httpp:!!! www.helsinnki.fi/ylioppilasmatrikkeli/1853-1899/ henkilo.php?id=24795. Frankenhaeuser ks. Leena Valkeapää, Pitäjänkirkosta kansallismonumentiksi: Suomen keskiaikaisten kivikirkkojen restaurointi ja sen tausta vuosina 1870-1920, SMYA 108 (Helsinki: Suomen Muinaismuistoyhdistys, 2000), 130. Frankenhaeuser oli ensimmäinen vuonna 1904 perustetun Muinaistieteellisen toimikunnan arkkitehtiamanuenssin virkaan valittu henkilö.

59 E. N. [Emil Nervander] "Taidetta etsimässä",

teoksessa Nuori Suomi Päivälehden joulualbumi IX (Helsinki: Päivälehti, 1899).

60 MV SMY pk 16.2.1899 §3 ja liite A.

61 Nervander, "Taidetta etsimässä", 41-43.

62 MV SMY pk 18.3.1897 §3.

63 MV SMY johtokunta pk 11.4.1901 §5, SMY pk

17.10.1901 §10.

64 MV SMY pk 7.5.1902 §6.

65 MV SMY, Vuosikertomus SMY:n 33:Ita

toimivuodelta 7.5.1902-7.5.1903.

66 MV SMY, Vuosikertomus SMY:n 31:seltä

toimivuodelta 7.5.1900-7.5.1901.
67 Vuosikertomuksen mukaan retken "saalis" oli 252 numeroa. Museoviraston valokuvaluettelossa "Hist. os. levyluettelo 1-13199 Hist. avd. plåtkatalog" numerot 1314-1495 on otsikoitu "VIII K. Hist Exp 1902". Valokuvia on siis 181 kappaletta, jolloin muiden kuvien osuudeksi jää 71 kappaletta. Lähteissä mainitaan paikat, joissa kuvia otettiin, mutta kuvia ei yksilöidä. Tiedot niistä on etsittävä ja pääteltävä kuvissa mahdollisesti olevista nimikirjoituksista ja päiväyksistä. Vuosikertomus Suomen Muinaismuistoyhdistyksen 33:Ita toimivuodelta 7.5.1902-7.5.1903. Myös Tallgren, Suomen Muinaismuistoyhdistyksen 50-vuotiskertomus, 79. 68 MV SMY johtokunta pk 10.10.1902 §6. 69 MV SMY Vuosikertomus 1902-1903. 70 MV SMY pk 5.3.1903 §5 ja Liite D, SMY kokous pk $1.10 .1903 \S 7$.

71 Tallgren, Suomen Muinaismuistoyhdistyksen 50-vuotiskertomus, 79.

72 Asiaa käsiteltiin marraskuusta 1902 lähtien. SMY johtokunta pk 5.11.1902. Tallgren, Suomen Muinaismuistoyhdistyksen 50-vuotiskertomus, 145-146.

73 SMY kokous pk 1.10.1903 §7.

74 Retkien järjestämistä tarjottiin Muinaistieteelliselle Toimikunnalle 1887 ja 1894. Tallgren, Suomen Muinaismuistoyhdistyksen 50-vuotiskertomus, 77 , 162.
75 Meinanderin suunnitelma julkaisuksi 4.2.1904, SMY pk 3.3.1904 §5 Liite B.

76 Valkeapää, "Tutkimusmatkalla Suomessa 1871", 45-48. Valkeapää, Vapaa kuin lintu, 124-125. Antti Vallius, Kuvien maaseutu: Maaseutumaisemakuvaston luomat mielikuvat suomalaisesta maaseutukulttuurista (Jyväskylä: Jyväskylän yliopisto, 2013), 371-372.

77 Raporttien sivut ovat erikokoisia, eri käsialoilla kirjoitettuja ja niiden kokoonpanossa on muitakin eroja, joten sivumäärä antaa lähinnä idean aineiston koosta.

78 Historiallisen osaston Kuvaluettelo 1842-1909 paljastaa, miten hitaasti kuvakokoelmat kasvoivat ennen vuotta 1871.

79 Rajaus tulee esille esim. vuoden 1892 retkellä, kun eräs ratatöiden yhteydessä läheltä Siuran asemaa löytynyt kilvenkupura dokumentoitiin, vaikka "se on varsinaisen ohjelmamme ulkopuolella". Nervander, "Från trakterna af Björneborgska banan", $\mathrm{Hbl}$ 20.2.1893 no 49. Ks. myös SMY:n taidehistoriallisten retkikuntien kertomukset, Retki 1892, mf rulla 3, ja kuvaluettelon no 242.

80 Aspelinin osalta ks. A. M. Tallgren, Museomiehen työpöydältä: Kirjoitelmia muinaistieteellisten ja antikvaaristen harrastusten historiasta Suomessa (Helsinki: Tietosanakirja-osakeyhtiö, 1924), 30.

Ringbom tiivisti Nervanderin olleen "romantiikan 
huipentuma"(a romantic climax), ks. Sixten Ringbom, Art history in Finland before 1920: The history of learning and science in Finland 1828-1918, 15b (Helsinki: Societas Scientiarum Fennica, 1986). 81 Keskiaikaisia kirkkoja koskeva argumentointi ks. Valkeapää, Pitäjänkirkosta kansallismonumentiksi, 165-167. Tanskan ja Suomen vertailu ks. "Suomen Muinaismuisto-Yhtiön vuosikertomus 24:Itä tilivuodelta". Suomen Museo 5/1894. Ks. esimerkki "köyhän kansamme etsikkoaika" -retoriikasta J.

R. Aspelinin puheessa SMY:n vuosikokouksessa 6.5.1899 §1.

82 Mads Mordhorst, "Arkivets historie", teoksessa Antikvarisk-Topografisk Arkiv: Afdelning for Oldtid og Middelalder (Kobenhavn: Nationalmuseet, 1996), 25-40. Tanskalaista mallia käytettiin suoraan SMY:n ohjelman laatimisessa ks. SMY pk 1.10.1870 §3, 15. 83 Sarjan ensimmäinen vihko ilmestyi nimellä Monuments scandinaviques. Mandelgrenista ks. "Riksarkivet: Nils Månsson Mandelgren", Luettu 18.10.2016, https://sok riksarkivet.se/sbl/Presentation. aspx?id=9011. Ruotsin muinaismuistosuojelun historiasta ja sen kirjoittamisesta ks. Magdalena Hillström, Ansvaret för kulturarvet: Studier i det kulturhistoriska museiväsendets formering med särskild inriktning på Nordiska museets etablering 1872-1919 (Linköping: Linköping University
Electronic Press, 2006), 43-48.

84 Alueellisia muinaismuistoyhdistyksiä ryhdyttiin perustamaan eri puolille Ruotsia 1850-luvulta lähtien. Hillström, Ansvaret för kulturarvet, 90-92, koko maan kattavan yhdistyksen perustamisesta 1869 ks. 104-107.

85 Vuonna 1828 säädetystä muinaismuistolaista ks. Hillström, Ansvaret för kulturarvet, 48.

86 Loppuvuodesta 1874 suunniteltiin pilaria, jonka akselissa liikkuviin tauluihin laskettiin mahtuvan 128 kuvaa. SMY pk 29.10.1874 §2, 274. SMY pk 9.11.1874 §3, 283.

87 Tallgren, Suomen Muinaismuistoyhdistyksen 50-vuotiskertomus, 74-78.

88 SMY pk 5.5.1880 §7, 204. SMY pk 3.6.1881 §2, 250.

89 Luettelo esineistä ensimmäisessä Suomen taideteollisuus-nä[y]ttelyssä Helsingissä 1881, Ensimmäinen vihko (Helsinki: Suomal. Kirjall. Seuran kirjapaino, 1881). Näyttelystä ks. Valkeapää, Vapaa kuin lintu, 91. Ks. myös Kerstin Smeds, Helsingfors-Paris: Finlands utveckling till nation på världsutställningarna 1851-1900 (Helsingfors: Svenska litteratursällskapet i Finland, Finska Historiska Samfundet, 1996), 178-180. 90 Esimerkiksi SMY johtokunta pk 10.11.1898 §3 ja 15,12.1898 §8, molemmat liitteineen.

91 "Suomen Muinaismuistoyhdistyksen vuosikertomus 29 toimivuodelta". Suomen Museo 5/1899, 80.

92 Näyttelyluettelo: Finska fornminnesföreningens konsthistoriska utställning i Ateneum, 12-28. Februari 1903. SMY Vuosikertomus 1902-1903, 3.

93 SMY pk 27.1.1874 §5, 238-239. SMY pk 4.1.1875 $\S 5,301$.

94 K. K. Meinander, "Finska Fornminnesföreningens konsthistoriska expeditioner", Suomen Museo Finskt Museum 1/1903, 2-3. SMY johtokunta pk 4.2.1904 §2. Pyydetyt lausunnot ja Meinanderin tarkennettu ehdotus SMY pk 3.3.1904 §5 ja liitteet B-E. Pöytäkirjoissa on yliviivattu sanat "tulevaan vuoteen" ja korvattu sanalla "toistaiseksi". Meinanderin vastauksesta käy ilmi, että hän ideoi hanketta yhdessä Lindgrenin ja Frankenhaeuserin kanssa.

95 Kuvat jaoteltiin ensimmäisestä näyttelystä lähtien kuvatun kohteen tekniikan mukaan neljään ryhmään: Arkitektur, Skulptur, Måleri ja Kyrkliga föremål, Ornamenter, slöjd m. m.

96 Tieto perustuu havaintoihini ja keskusteluihin arkistovirkailijoiden kanssa. Hirn teki Suomen Muinaismuistoyhdistyksen juhlavuoteen liittyvää inventointia, jonka tärkeänä tuloksena oli kirjan julkaiseminen vuonna 1970. Ks. viite 2. 97 Museoviraston Kuvakokoelmat: https://wwww. kuvakokoelmat.fi/. Yksittäisten retkien digitoituja kuvia 
yhdistää yhteinen tunnistenumeron alkuosa, näin esimerkiksi ensimmäisen retken kuvien numero alkaa sarjalla 18711016 ja viidennen retken kuvat sarjalla 18921029. Numerosarjan jälkiosa on yksittäisen kuvan retken kuvaluettelossa saama järjestysnumero, esimerkiksi 18711016:1. Kaikki retkien I-VII

katseluhetkeen mennessä digitoidut kuvat saa esille Museoviraston päätelaitteella kyseisen retken tunnistenumeron ja \%-merkin avulla.

FT, dos. Leena Valkeapää on sääksmäkeläinen 1800-luvun kulttuurihistoriaan erikoistunut Jyväskylän yliopiston taidehistorian oppiaineen dosentti. Hän tutkii menneisyyden käyttöä ennen ja nyt sekä merkitysten muuttumista historiassa ja taiteessa. Valkeapää on julkaissut tutkimuksia ja tietokirjoja muun muassa Suomen keskiaikaisten kivikirkkojen restauroinnin kulttuurihistoriasta, Kalannin alttarikaappiin liittyvistä uskomustarinoista, Ritvalan helkajuhlasta ja kansallispukujen käytön alkuvaiheista sekä Taidehistorian seuran kustantaman elämäkerran Vapaa kuin lintu, Emil Nervanderin elämä. Parhaillaan Valkeapää tutkii

\section{Koneen Säätiön rahoituksella Suomen}

Muinaismuistoyhdistyksen vuosina

1871-1902 järjestämiä taidehistoriallisia

tutkimusretkiä. 